Notre Dame Law School

NDLScholarship

Journal Articles

Publications

1998

\title{
The Hughes Court and Constitutional Consultation
}

Barry Cushman

Notre Dame Law School, bcushman@nd.edu

Follow this and additional works at: https://scholarship.law.nd.edu/law_faculty_scholarship Part of the Legal Commons

\section{Recommended Citation}

Barry Cushman, The Hughes Court and Constitutional Consultation, The Journal of Supreme Court History, Vol. 79, 1998. Available at: https://scholarship.law.nd.edu/law_faculty_scholarship/295

This Article is brought to you for free and open access by the Publications at NDLScholarship. It has been accepted for inclusion in Journal Articles by an authorized administrator of NDLScholarship. For more information, please contact lawdr@nd.edu. 


\title{
The Hughes Court and Constitutional Consultation
}

\author{
Barry Cushman*
}

Our conventional image of the Supreme Court under Charles Evans Hughes calls to mind the riddle of the Sphinx: What creature walks on four feet in the morning, on two at noon, and on three in the evening? The answer with which Oedipus rescued the city of Thebes from a reign of terror was, of course. "Man": he crawls on all fours in infancy, stands crect on two legs in adulthood, and leans on a staff in old age. The established story of the Hughes Court inverts the chronology somewhat, but the characters are the same. In the mid-1930s, the crotchety Nine Old Men impetuously flouted the popular will, eviscerating the New Deal. Chastened by the disciplining hand of a stern presidential father figure in 1937, a repentant Court was "reborn," then blossomed into beauliful but uncertain youth under Harlan Fiske Stone and Fred Vinson, and grew into mature adulthood under Earl Warren.

The story has its charm, and a certain simple elegance. It has for many years captured the imagination of a great many ex tremely able and distinguished scholars. In my own impetuous youth I have come to conclusions that differ from theirs. But I will not belabor all of my reasons for reaching those conclusions here, for it is not my immediate objective to convert you to my view of the matter. I ask only that you suspend disbelicf. Forget for a moment, if you will, that the Justices invalidated New Deal initiatives because they thought them unwise social policy: forget that they later upheld federal regulations only because the Court-packing plan put the fear of God into them; forget that they continued to do so only because they had seen the light. Forget that the Court's role under Hughes was entirely reactive: first obstructing, then surrendering to, the political branches. This will, of course, be disorienting. But if all of this forgetting has not already rendered you unconscious, il may enable us to see the Hughes Court and its role in the New Deal saga in a new light. 
Franklin Delano Roosevelt was the greatest politician of his age. But he was not the greatest constitutional lawyer. For exanple, he had rather unorthodox views on questions of the separation of powers. Early in his first term, the President approached Chief Justice Hughes and suggested that the two of them form a sort of consultative relationship. As one contemporary account has it, Roosevelt "intimated that he would like to talk over with the Chef Justice all his important plans concerning the general welfare, to get the Court stant on them before acting " Article III, Section 2 of the Constitution provides that the judicial power of the United States shall extend only to certain speci. fied cases and controversies. and the Supreme Court had first declined a presidential requesi for an advisory opinion in George Washington's second term, when the first Presdent had souglut counsel on specific questions of untemational law: Hughes similarly demurred to Roosevelt's overtures, informing the Presi- dent that "the Supreme Court is an independent branch of government." As one account puts it, "he turned the President down flat." Roosevelt related this story while defending his Court-packing plat to a doubiful Senator. "You see," the President sighed, "he wouldn't comoperate."

There is. I suggest, no little trony in this defense of the effort to pack the Cour. For in ways that Roosevelt apparently did not fully appreciate, but which others did, the Court was in fact cooperating with the political branches in seeking to formulate constimutional solutions to the economic crisis of the 1930s. Thope to ill uminate this phenomenon by sketching a series of vignettes involving the fate of several Depression-era programs. Through these thope to show that within the channels prescribed by Article III, and occastonally outside them as well, the Hughes Coun offered the Roosevelt administration a distnctive form of consulta. tive relationship.

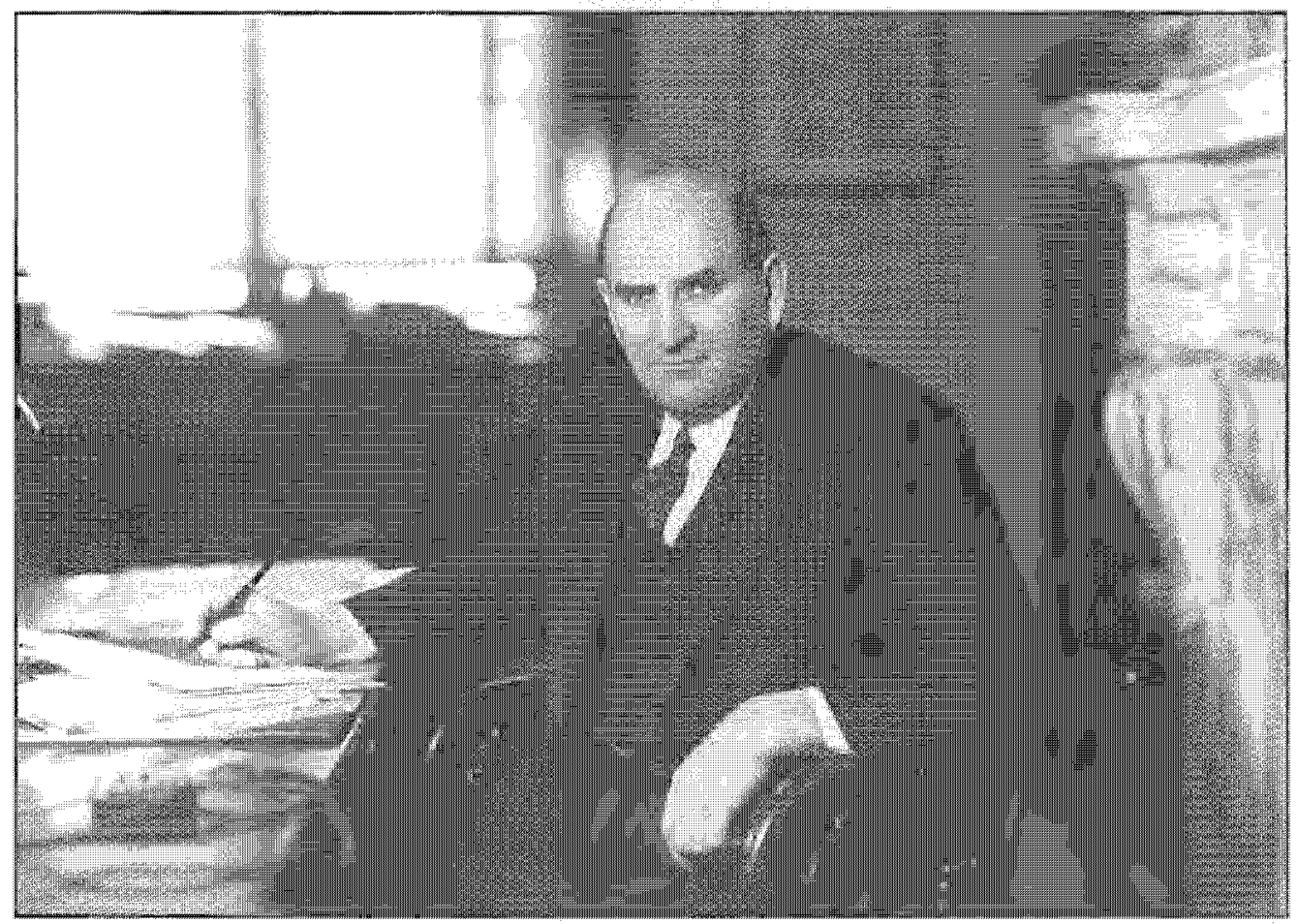

Semater Lyn Joseph Frazer (nove) was one of the athors of the Trather-Lemke Fom Debt Gelief

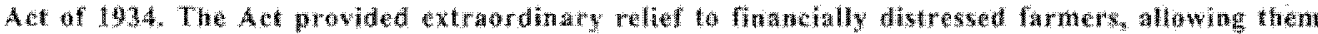

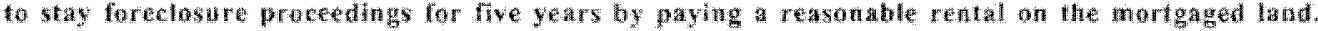

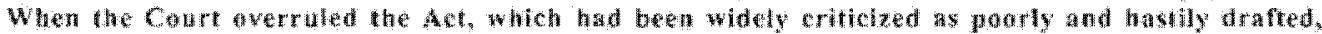

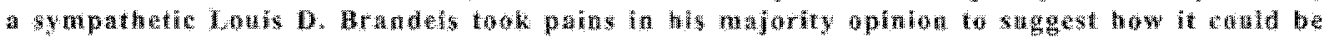
rewhed to pass eomstitutional muster. 
Consider, for example, the Frazier-Lemke Farm Debt Relief Act of 1934. The Act provided extraordinaty relief to financially distressed farmers, allowing then to stay foreclosure proceedings for five years by paying a reasonable rental on the mortgaged land. At any tinie during this period the debtor could take title to the land free and clear of any mongage simply by paying its appraised value-even if that value was substantially less than the amount of the mortgage debt.

The Act "inspired a storn of controversy [over] its validily." Commentary in the law jownals characterized the Act as "hastily drafted and hurriedly passed" "by a harried Congress," rushing it "through as last minute emergency legislation." It was criticized as "one of the worst recent examples of draftsmienship in Federal legisiation." "t "The failure of its ultimate passage even was fenred at times, " noted one observer." It was enacted "[d]espite. . the doubts of many members of Congress," $I Z$ and "the fears of its proponents were not allayed when the President retained the bill for ten days before signing it"la "with apparent hesitation and misgiving." $A$ the signing ceremony Roosevelt presciently remarked, "The bill is in some respects loosely worded and will require anjendment at the next session of Congress."

The Act's constitutionality was challenged before the Court in the Spring of 1935 in the case of Louisville Joint Stock Land Bank $v$. Radford $^{36}$ The Justices of the Supreme Court were unanimously of the opinion that the Act transgressed limits imposed by the Due Process Clause of the Fifth Amendment. Chief Justice Hughes assigned the opinion to Justice Louis D. Btandeis, who had great sympathy for the plight of distressed small farmers and for the objectives of the Act. ${ }^{17}$ Brandeis did not squander the opportunity presented by the assignment. He offered a thitty-page examination of the history of legislative attempts to provide relief for distressed motgagors, in which he painstakingly identified the ways in which the Frazier-Lemke Act entarged these protections beyond anything previously sanctioned by the Court. The Justice did not confine himself to identifying one or two deficiencies of the Act and leave Congress guessing whether other features of the Act would require revision in order to pass constitutional muster. Instead, he listed five specific substantive rights of the creditor that the Act infringed. As one comment in the Cornell Law Review noted, the Court "definitely showed that it appreciated the situation which led to this drastic measure.... It indicated that similar legislation might be upheld if it were found to preserve substantially the rights of mortgagees."

The Radford case was handed down on "Black Monday"-May 27, 1935. That same day the Court unanimonsly drew the curtain on the brief career of the National Industrial Recovery Act in the famous "sick chicken" case, Schecher Poultry v. United Stales. Immediately following delivery of the decisions, Brandeis pulled Roosevelt lieutenant Ben Cohen aside and told him "The President has been living in a fool s paradise. . . I should not be surprised if everything would have to be redrafted. "zo Brandeis' mcssage was clear. The Count. despite its unanimity, was not saying that the federal government was powerless to address the economic crisis. Had this been the import of the decisions, there would have been little sense in redrafting anything. Brandeis point was instead that the crisis would have to be addressed with measures consistent with the Constitution. And Brandeis opinion in Radfort, with its meticulous discussion of the Act's constitutional infirmities, provided illuminating advice on how the statute ought to be redrafted.

And redrafted st was. ${ }^{2 k}$ Within ten days of the Radford decision Senator Frazier had introduced a revised bill, and by the first of July the Senate Judiciary Committee had issued a unanjmous favorable report with amendments. ${ }^{22}$ "Their task was simplified," noted one observer, "by the opinion pointing out the constitutional defects of the former Act. . ." The result, as another put it, was a "more carefully drawn" statute that sought "to cure the flagrant defects summarized by the Coutt." 24

When the bill reached the floors of the House and Senate, several legislators asked whether the revised bill had rectified the constitutional deficiencies of the first Act, and its many proponents uniformly professed confidence that it had ${ }^{\text {?s }}$ Senate Iudiciary Committee Chairman Henry Ashurst was one among 


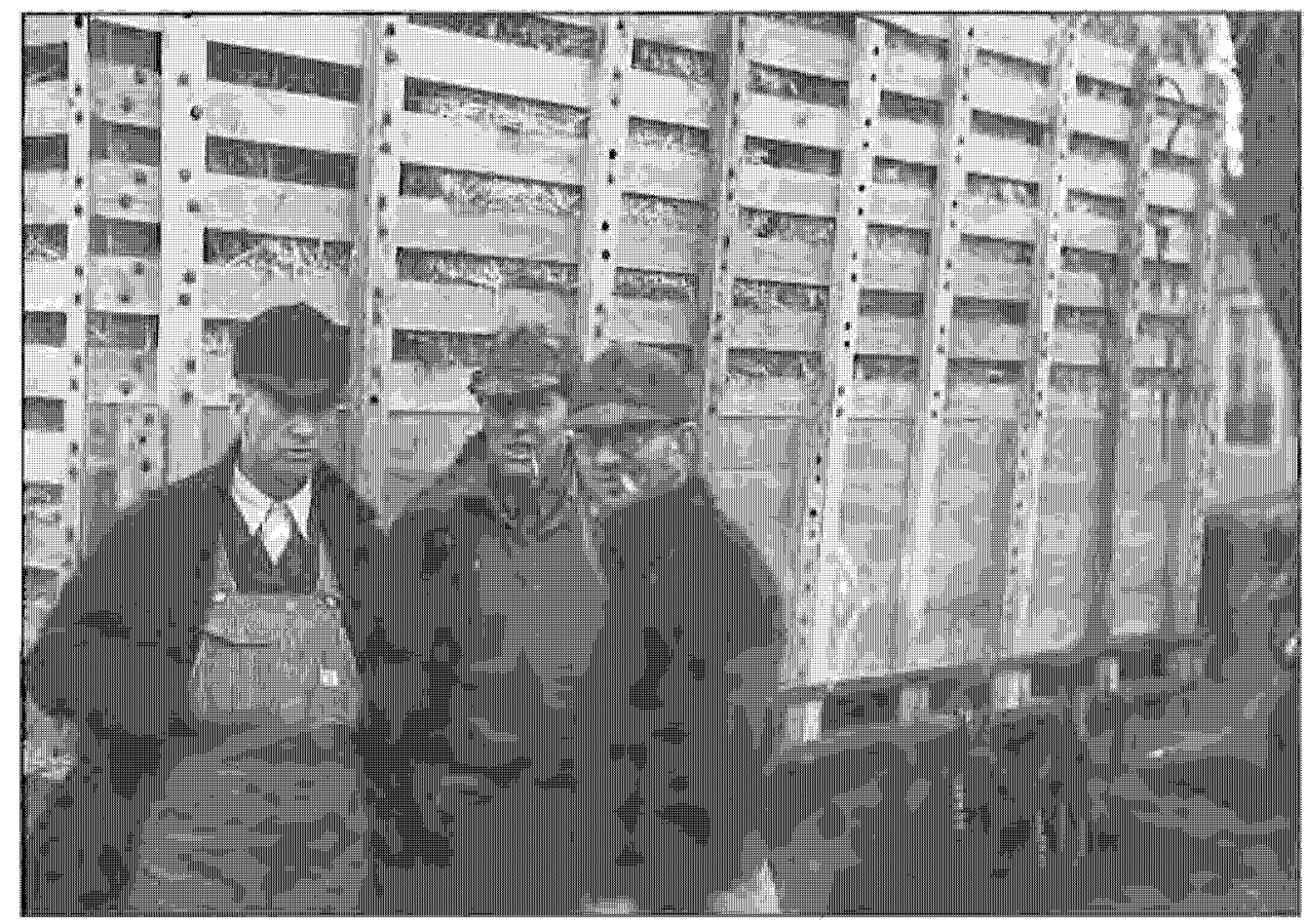

many who assured his colleagues that "This bill is an earnest and, I believe, an able effort to meet the objection announced by the Court. . without any attempt to defy the Court or to circumvent the Constitution...." The old ldaho Progressive Senator Wilian Borah testified that he had voted against the first Frazier-Lemke Act solely because he had thought it unconstitutional, but that he sup. ported the revised bill, which he believed cond run the judicial ganntlet. Floor amendments removed or modified any remaining provisions over which members had constitutional qualms, and the bill then passed both chambers without a dissenting vote ${ }^{29}$ A comment in the Columbia Law Review predicted that "Since those features of the original act which the Court found chiefly objectionable have been eliminated, the revised statute will probably be held consistent with due process...."

When the constitutionality of the new Act was challenged before the Court in Wrigh : Vinton Branch Banl" in early 1937, the debtor emphasized the efforts of Congress to remedy the faults of the first Act. The new Act, he as- serted, was "the result of a painstaking artempt by Congress to comply with the decision of this Court holding the first Frazier-Lemke Act unconstitutional." Af ${ }^{3}$ Afer recounting the legislative history of the statute and detailing its improvements upon the old Act, ${ }^{3}$ the debtor's brief concluded: "We are not here concemed with the decision of the Supreme Court holding the original Frazier-Lente Act unconstitutional. This is not the same act, but a new act drafted carefully so as to comply with the mandate laid down by the Supreme Court in that decision." "\$4

The Justices did vote to uphold the second Frazier-Lemke Act, and Hughes again assigned the opinion to Brandeis. "The decision in the Radfond case did not question the power of Congress to offer to distressed farmers the atd of a means of rehabilitation under the bank ruptcy clause," wrote Brandeis. It had merely held that the lirst Act violated the Fifth Amendment by infringing the five substantive rights there enumerated. "In drafting the new FrazierLemke Act," Brandeis observed, "its framers sought to preserve to the mortgagee all of these rights so far as essential to the enjoyment of his security. The measure received careful con- 


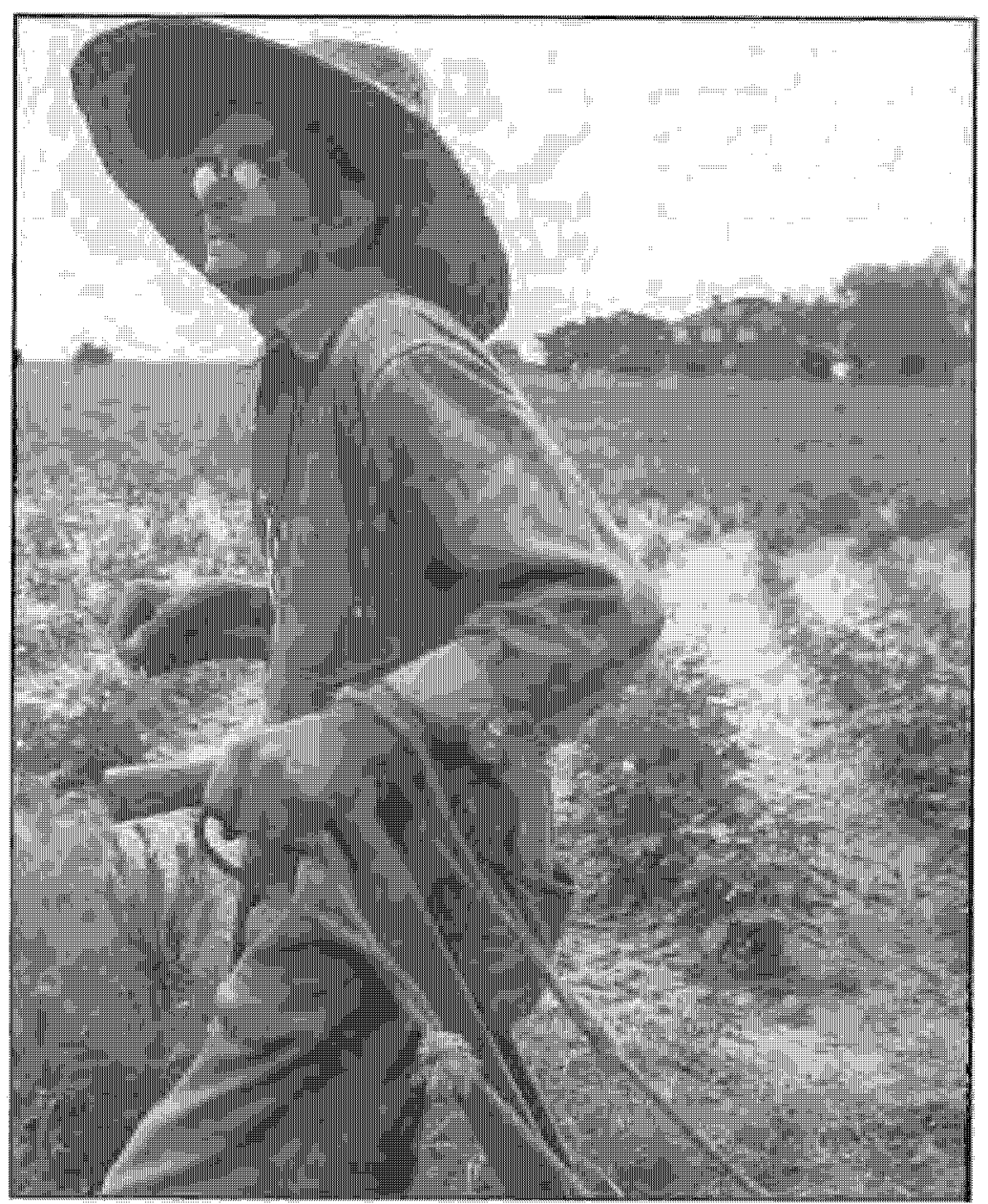

In 1937 Dorother

donne phowographed

Soufl Caralina sharecopper (unto). and Russell Lee captuatad lowa chicken forments (owpositu), for He Furm security Administration's

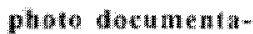
man prodram. The reviled FrazierConkw bull wa mplustu by He Cour and provided mach aceded belp to desperate Iarmers. sideration before the committees of the House and the Senate. Amendments were made there with a view to ensuring the constitutionality of the legislation recommended. The Congress concluded, after full discussion, that the bill, as enacted, was free from the objectionable feaures which had been held fatal to the original Act. "3randeis explained how the new Act remedied cach of the defects his Radford opinion had identified, demonstrating at each step a thorough mastery of the Act's legislative history. His opinion noted approvingly that "Emphasis upon the deliberate intention to meet the constitutional objections raised in [Radford dominated the consideration of the bill in all stages. "A6 "Amendments to the bill subsequent to its introduction plainly demonstrate[d] careful intention to leave the [creditor's] hen wholly urimpatred." The Court concurred in the congressional judgment that the provisions of the revised Act made no unreasonable modification of the creditor ${ }^{*} \mathrm{~s}$ rights, and hence were valid

The Wrigh opinion was announced on March 29, 1937, at the height of the controversy over the President's Court-packing proposal. That same day the Court upheld Washington state"s minimum wage statute, wo weeks later the Count upheld the application of the National Labor Relations Act to three manufacturing concerns, in May the Court upheld the unemployment insurance provisions of the Social Security Act as well as Alabama"s complementary state unemployment compensation act." These decisions have often been characterized, erroneously in my vicw, as jurisprudential about-fices, reactions to such external pressures as Roosevelt"s landslide olec- 
tion in 1936 and/or the Court-packing plan. In those cases, it is contended, the Court capitulated to the New Deal in order to defuse the Court-packing threat. Could it not be contended with cqual force that the Court's decision to uphold the second Frazier-Lemke Act was similarly motivated?

I don't think so. For even if we assume that the conventional explanation of the more famous decisions of the spring of 1937 is correct. the Wright case stands on a different footing. For all of the other cases to which $I$ have alluded were decided by votes of 5 to 4 . Notwithstanding the pressures brought to bear by the election and by the Coutt-packing plan. the Four Horsemen continued to cast vores against major initiatives for social reform in the most celebrated cases of the day. The vote in the Wright case, by contrast, was unanimous. Sutherland, Butler, Van Devanter, and McReynolds were all with the majority. Given their voting records before, during, and after the Court-packing crisis, it seems unlikely in the extreme that they voted to uphold the second Frazier-Lemke Act for any reason other than that they thought it was constitutional. $\mathrm{A}$ much more persuasive assessment was offered by a contemporary commentator in the Columbia Law Review, who remarked, "this is a dramatic illustration of the manner in which by carefi] draftsmanship Congress can overcome constitutional objections when they are explicitly stated, and thus in a șubstantial measure atrain the objectives sought by previously invilidated legisiation." 4 ?

A second national regulatory initiative struck down by the Court in 1935 was section $9(c)$ of the National Industrial Recovery Act. ${ }^{43}$ In an effort to stabilize petroleum prices in the face of a frenzy of wildcat drilling in the East Texas oil fields, Congress authorized the President to prohibit interstate transportation of what was called "contraband" or "hot" pil-that is, oil produced in excess of the amount permitted by the law of the state of production. The President had done so by executive order, and had in turn delegated authority to promulgate appropriate nules and regulations to the Secretary of the Interior. The President had by further executive order approved a Code of Fair Com- petition for the Petroleum Industry. Two petroleurn companies sought to restrain enforcement of various provisions of the oil regulation program. $^{* 4}$

The litigation of the Hot Oil Cuses was something of a fiasco. Unbeknownst to both the oil companies and the government lawyers, a provision of the Petroleum Code at issue had been inadvertently repualed by a subsequent executive ordor before the suits had been initjated. The Attorney General's office had been unknowingly defending the constitutionality of a provision that was not even law. Socretary of the Interior Harold Ickes wrote in his diary that it made him sick when he thought of the way the Justice Department's representative had haudled the case before the Suprenc Court. Yet notwithstanding a poor performance by the attomeys for the government, the Chief Justice still nanaged to nake a little lemonade.

In an opinion written by Hughes, the Court by a vote of 8 to 1 held that section 9 (c) consttuted an unconstitutional delegation of legislative authority to the executive. "[I]n every case in which the question has been raised," Highes observed, "the Cour has recognized that there are linits of delegation which there is no constitutional authority to transcend. We think that section 9(c) goes beyond those limits. "4/7 Hughes patiently teviewed the development of the Court's delegation jurisprudence from the years of the early republic to the 1930 s, showing how each delegation previously susrained had satisfied criteria that were unmet in the instant case." "As to transportation of oil production in excess of state permission," he maintained, "the Congress has declared no policy. has established no standard, has laid down no rule." "Section $9(\mathrm{c})$ does not state whether. or in what circumstances or under what cond tions, the President is to probibit the transportation. . . It establishes no criterion to govern the President's course. . . So far as this section is concerned, it gives to the President an unlimited authority. , . " 50

But as Hughes' opinion made clear, this problem was not irremediable. For as the cases showed, "Congress. . . may establish prinary standards, devolving upon others the duty to carry out the declared legislative policy, that is, 
as Chief Justice Marshall expressed it 'to fill up the details' under the general provisions made by the legislature." "If Congress shall lay down by legislative act an intelligible principle to which the person or body authorized to [act] is directed to conform," Hughes counseled, "such legislative action is not a forbidden delegation of power." 5 ?

Readers of the opinion were confident that the defects identitied by Hughes could be "easily remedied." As one commentator observed, "That the decision of the Court was limited to the pronouncement that the "primary standard" was too vague, in effect, suggests that there is a proper way to accomplish the end desired, i.e., Congress may set out definitely such a standard, "kepresentative Charles Wolverton maintained that a standard adequate to satisty the Court "could have been placed in section $9(c)$ by the use of only a few words." "The re quirement that the statute provide some standard to guide the President, observed another, "relates merely to the form of legislative drafting. As pointed out by one writer, "the effect of the decision might be very like that of the Statute of Uses which has been said merely to have added six more words to every English conveyance ${ }^{2 * 5 s}$

At the height of the Court-packing fight, Roosevelt would contend that the series of decisions invalidating New Deal inftiatives meant that the government was powerless in the face of grave economic crisis. In early 1935 , however, he was much less pessimistic. At a press conference following the Court's dectsion in the Hor Onl Cases, the President told reporters, "You and 1 know that in the long tum there may be half a dozen more cout decisions

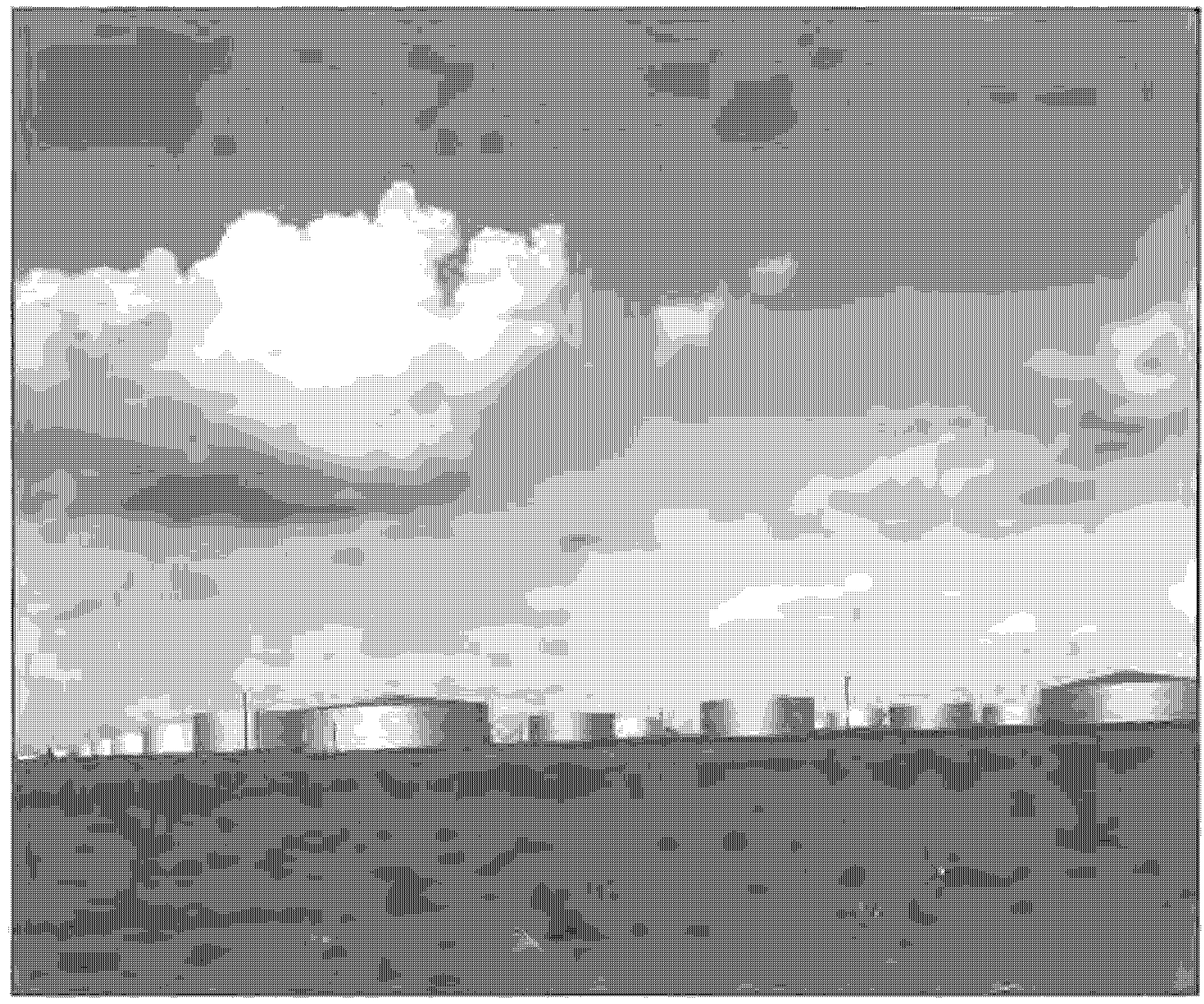

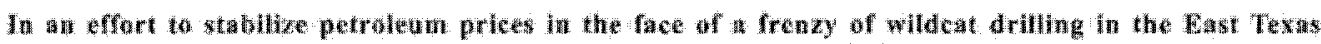
oll flelds (above). Comgress anthorized the President to probibit interstate transportation of what was called "contraband" or "hot" oillmathat is, on produced in excess of the amount permited by the law of the state of production. Chef Justice Charles Evans Hoghes" apinion th the Hot on Cases struck down the regulatory iniliative as an unconstitutional delegation of legislative authority to the encentive, but went out of its way to advise Congress on how lo remedy lhe statute's defecta. 
hefore they get the correct language, before they get things straightened out according to correct constifutional methods. "56 Harold lckes surely took encouragement from a conversation he had with Justice Roberts at a dinner party three days after the Court announced its decision. Ickes recorded in his diary that Roberts "assured me that he is entirely sympathetic witl what we are trying to do in the oil matter and that he hoped we would pass a statute that would enable us to carry out our policy."

Eleven days after the Court announced its decision in the Hot Oil Cases, Senator Tom Connally of Texas introduced legislation to rectify the problems identified in the Chief Justice"s opinion. ${ }^{5 B}$ Connally, who affirmed his belief that the Hor Oil Cases had been correctly decided, ${ }^{59}$ assured his colleagues that his bill "was drawn in collaboration with the legal authorities of the Department of the Interior and has been carefully scrutinized by the oil production board and their legal staff." They all joined the members of the Senate Committee on Mines and Mining in believing "that the prcsent measure obviates the objections which wete urged to the act before the Supreme Court." The new bill's solution to the delegation problem was anestingly simple. Rather than delegating authority to prohibit interstate shipment of hot wil to the President, Congress itself prohibited such shipment by statute. "While the Supreme Court did not in so many words hold that the Congress had authority to prohibit" such shipments, Connally maintained, "there is every suggestion in the opinion that in the original case if Congress itself had prohibited the interstate shipment of this oil it would have been better. ..." The bill passed both houses of Congress without a record vote within six weeks of the Court's decision. ${ }^{62}$

Observers were confident that the Connally bill would pass muster before the Court. "[I]t would seem," wrote one, "that Congress has effectively met the objections expressed by the Court to the former Act." "[C] "[Crective legislation," wrote another, "has already been accomplished by the Conrally Bill...." " $[$ T] $]$ he immediate damage caused by the decision in the [Hol OH] case," remarked a third, "is repaired." ${ }^{65}$ These assessments were vindicated in duc course. Attacks on the constitutionality of the Act were uniformly rebuffed in the lower federal courts. ${ }^{\text {tit }}$ When an indictment for violation of the Act finally came before the Supreme Court in 1939, long after the Court-packing plan had been decisively repudiated, the defendants did not even challenge the Act's constitutionality. And the unanimous opinion sustaining the indictment was joined even by the two remaining Horsemen, Justices Pierce Butler and James C. McReynolds. ${ }^{\text {t }}$

Just as overproduction had created turmoil in the petroleum industry, cutthroat competition in the bituminous coal industry exerted di sastrous downward pressures on prices, wages, and working conditions. In an attempt $10 \mathrm{im}-$ pose order on this chaotic situation. Congress enacted the Guffey Coal Act of 1935. One part of the Act tegulated the price at which coal moved in interstate commerce. ${ }^{\text {ix }}$ Another part provided for regulation of wages, hours and labor rclations at the mines. ${ }^{\text {ig9 }}$ Members of both houses were plagued by doubts about the constitutionality of the labor provisions, and the Roosevelt administration had to resort to extraordinary measures to secure a favorable committec report. The bill passed both houses by unusually slin margins; and the sentiments of many were summed up by Senator Millard Tydings ' ominous forecast of the Act's future: "Like an autumn flower it will be blown away by the first winter blast of the Court. 70

The Count did hold the labor provisions unconstitutional in Carter . Carter Coal $\mathrm{Co}^{7}$ in 1936. The majority opinion did not, however, rale on the validity of the price regulation provisions. Instead, the majority found that those sections were inseparable from the offending labor provisions. Accordingly, the entire statute had to fall. ${ }^{72}$ Hughes wrote separately, agreeing that the labor provisions were invalid, but contending that the price provisions were valid, and were severable from the labor provisjons. " Benjamin N. Cardozo, joined by Brandeis and Stone, agreed in dissent that the price regulation provisions were valid and severable. ${ }^{74}$ Moreover, Cardozo noted suggestively, "Stabilizing prices would go a long way toward stabilizing labor relations by giving the producers capacity to pay a living wage. ${ }^{+7 s}$ If Congress could enact a law regulating the minimum price at which coal moved in interstatc 


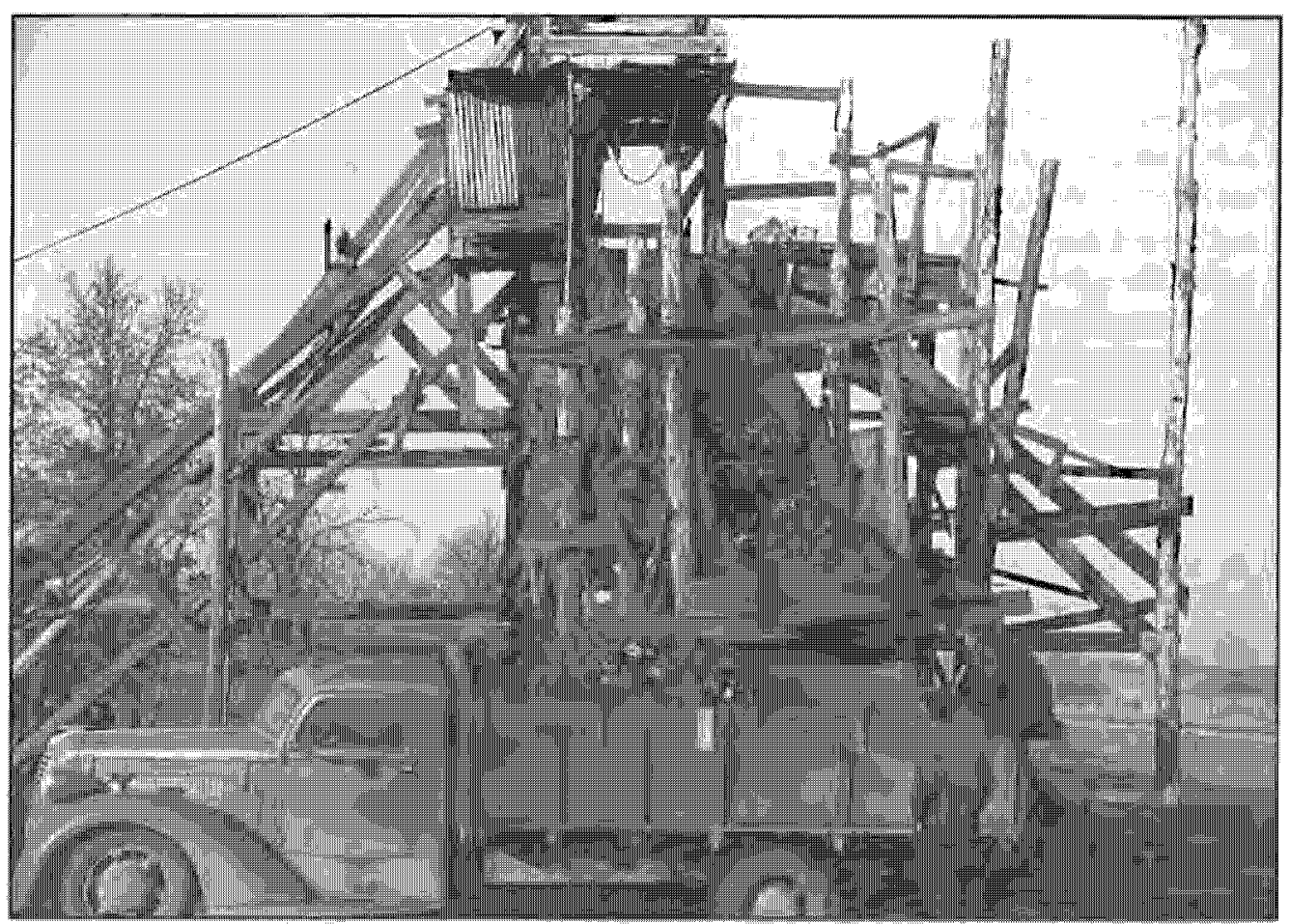

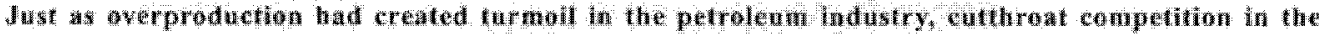
bituminous coal Industry exerted dsantrows downward pressures on proes, wages, and watking

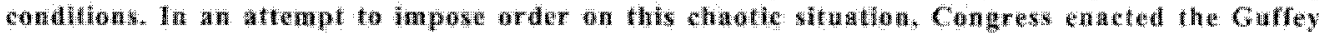

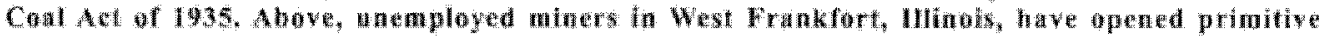

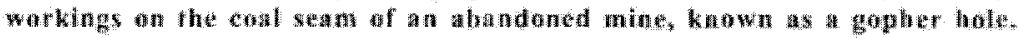

commerce, the dissent intimafed, many of the labor diffeulties caused by cutthroat price competition might be ameliorated as a result ${ }^{\text {ro }}$. And the opinions of Hughes and Cardozo, coupled with the fact that the majority opinion had refrained from declaring the price provisions themselves theonstitutional, suggested that such an act might well pass constitutional muster."

In the late winter and early spring of 1937 , Congress framed just such a bill. The Bituminous Coal Conservation Act of 1937 essentially resnacted the Guffey Coal Act without the objectionable labor provisions. ${ }^{3 x}$ Both in the committee reports and on the floor, sponsors repeatedly quoted from the Hughes and Cardozo opinions, emphasizing the limited scope of the majority opinion as they did so." Everyone knew that each of the Four Horsemen held very restrictive views of govemmental power to regulate prices, and it was atmost certain that they would have been prepared to invaltolate regulation of coal prices on the merits. ${ }^{\text {id }}$ Supporters of the bill therefore believed that the only reason that the Carter majority opinion had not squarely addressed the Guffey Act's price prom visions was that Justice Owen J. Roberts dic not consider them unconstitutional. After all, they pointed out, it was Roberts who had written the landmatk opinion upholding broad govermmental power to regulate prices in the 1934 case of Nebbia v. New York. If between 1934 and 1936 Roberts had "had any change in mind relative to the power of Congress to regulate prices," contended Representative Fred Vinson, "it would have been an easy matter to have invalidated those points" of the Guffey Act. ${ }^{82}$ Members of Congress thus interpreted the opinions in Carter Coal to mean that a majonty of the Court would approve a separate price regulation measure. ${ }^{*}$ Solicitor General Stanley F. Reed testified to his view that the bill was now constitutional, and its backers in Congress were optimistic about its prospects before the Court. ${ }^{84}$ Even Senators and Representatives 
who had opposed the Guffey Act on constitu* tional grounds announced their suppont for the revised bill. ${ }^{85}$ As Senator Guffey put it, "The bill is drawn so as to bring it clearly within the light of limitations which constitutional interpretation has imposed upon the power of Con gress." "As a lawyer and a Mamber of this body, I say to you that we have tried to square the languge of this bill with the dectsons of the Suprene Court." Vinson told hats colleagues. "Our efforts have not been to cincumvent any opinion of our highest court but we have worked in a bona fide atempt to meet the law laid down by them in a proper, legal, constitutional manner." "s,

When the 1937 Act was upheld by the Tughes Cont in 1040, onl Instice MeReynolds dissented. "There is nothing in the Carter case which stands in the way wrote Jistice Will lam O. Douglas, echoing aryuments made an
Congress three ycars before. "The majority of the Courtin that wase did not pass on the pricefixing provisions of the earlier Act. The Chief Justice and Mr. Justice Cardozo in separate mitorty upinutus expressed the vew that the price fixing features of the earlier act were con" stitutionat. We rest on their conclusions for suctaining the present Act. ${ }^{\text {Bg }}$

Yet another federal inthative invalidated by the Court in 1935 was the Railroad Retirement Act of 1934, Enacted under the aegis of the Commerce Power, the Act set up a system of compulsory retirement for employees of interstate cariers, ander which all such employees and cartets were required to contribute to a federal fund from which annities would be paid to setiees. The majority opinton was written by Justice koberts, who opened with the broadminded antouncenent that cour duty. . is furly to construe the pewers of Congress and

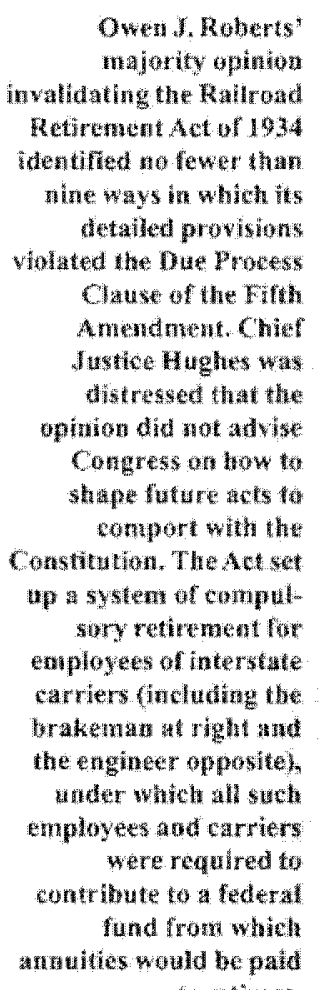
ro retinges.

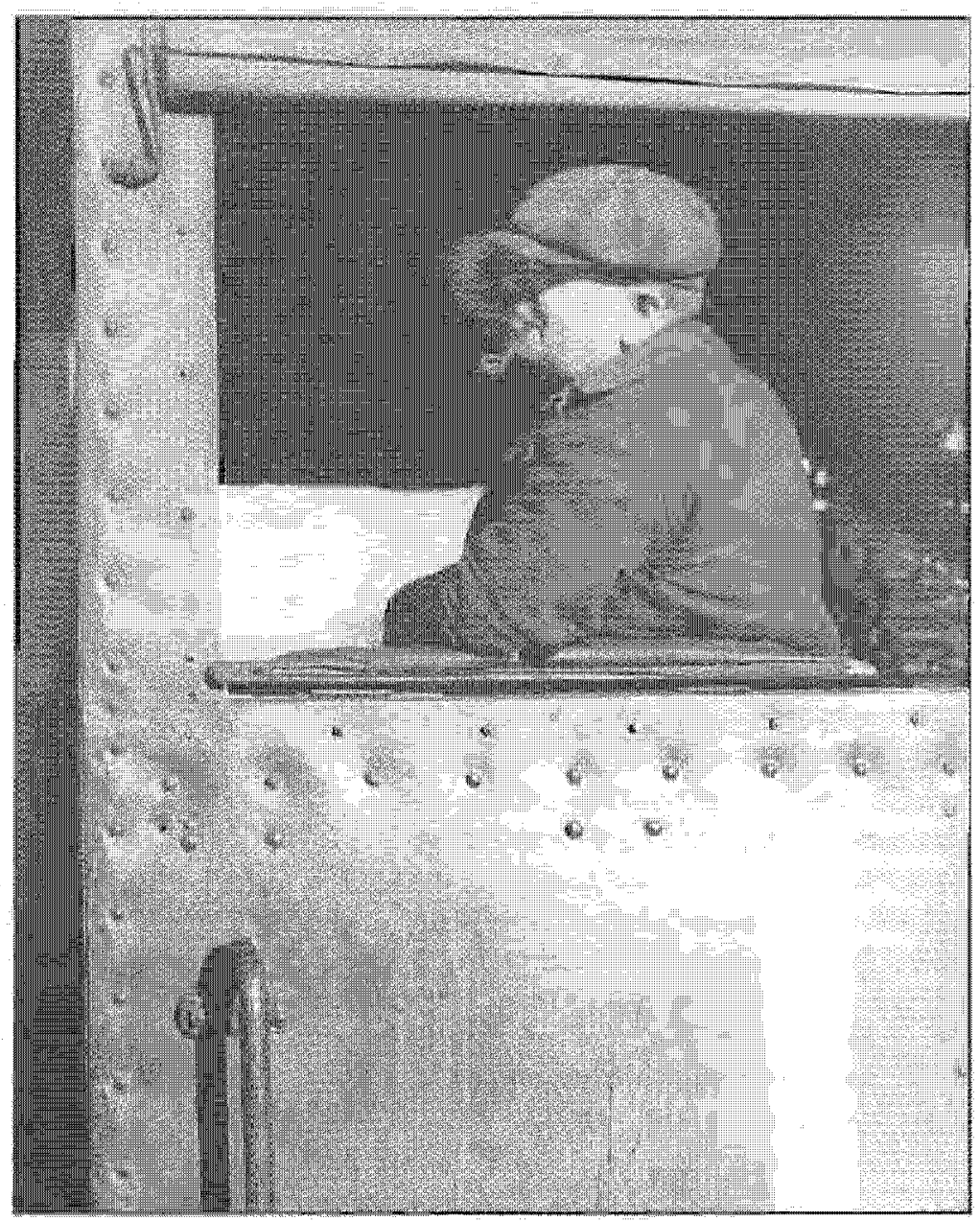


to ascertain whether or not the enactment falls within them, uninfluenced by predilection for or against the policy disclosed in the legistation." Roberts then proceeded to bludgeon the Act to death, identifying no fewer than nine ways in which its detailed provisions violated the Due Process Clause of the Fifth Amendment." Having pummeled the Act to a bloody pulp, Roberts then administered the coup de grace: even were all of the due process defects of the statute rectified, it would still be unconstitutional, for it was "not in purpose or effect a regulation of interstate commerce within the meaning of the Constitution. $"$ s:

Hughes was clearly distressed. The majority, in his view, was not performing its appropriate consultative function. It was not advising
Congress on how to shape future enactments so as to comport with the requirements of the Constitution. It was instead erecting an insum perable obstacle to any such ameliorative legislation. "If the opinion were limited to the particular provisions of the Act, which the majority find to be objectionable and not severable," he complaned in dissent, "the Congress would be free to overcome the objections by a new statute. ..." "What was. . found to be inconsistent with the requirements of due process could be excised and other provisions substiruted. But after discussing these matters, the majority finally raise a barrier against all leg. islative action of this nature by declaring that the subject matter itself lies beyond the reach of congressional authority to regulate interstate commerce. In that view, no matter how suitably

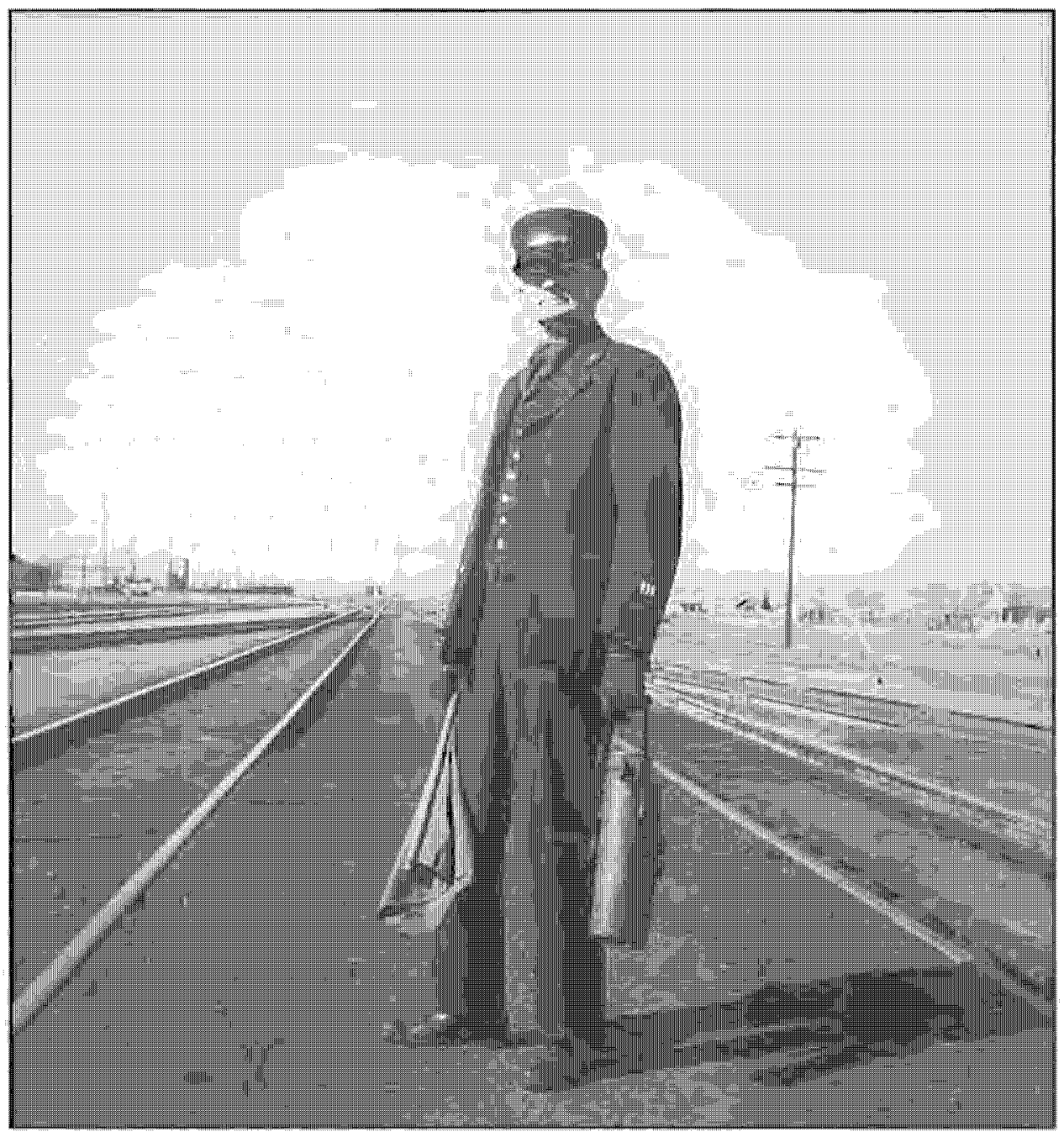


limited a pension act for railroad employees might be. . still under this decision Congress would not be at liberty to enact such a measure." "The gravest aspect of the decision," Hughes remarked gravely, "is that it does not rest simply upon a condemnation of particular features of the Railroad Retirement Act, but denies to Congress the power to pass any compulsory pension act for railroad employees."

This lament was echoed by Cassandras in the law reviews, ${ }^{\text {sh }}$ but it proved to be unwarranted. In the April issue of the St. Louis Law Review, Ralph Fuchs played the contrarian. "The decision of the Court does not in reality exclude the power of Congress," he maintained. "No reason appears why Congress could not levy a payroll tax upon the carriers and provide also for the payment of pensions to retired employees out of the Treasury." ${ }^{\text {"07 }}$ In other words, what Congress could not accomplish through its Commerce Power it might nevertheless be able to achieve through its powers to tax and spend. "To guard against an adverse decision upon a pension law enacted under the taxing power" Fuchs cautioned, "it might be wise to separate the taxing measure and the law authorizing the payment of the pensions. "9r Fuchs" theory was that the tax, considered separately from the pension payments, would be upheld as a legitimate revenue measure. And the appropriations to pay the pensions, separately considered, would similarly survive constitutional challenge-though for different reasons that I will explain momentarily."

That summer Congress followed the course mapped out by Fuchs, though it did so without much subtlety. ${ }^{\mid(x)}$ H.R. 8651 became the Railroad Retirement Act of 1935;:101 H.R. 8652 be canne the Cartier Taxing Act of 1935. ${ }^{102}$ The Taxing Act was calibrated to generate the amount of revenue necessary to fund the pension payments authorized by the Retirement Act. This stratagem set off something of a chase scene in the Senate. Opponents of the plan, while stopping short of frankly accusing their colleagues of subterfuge, tried to get the plan's sponsors to confess that it was an attempt to cireumvent the Court's decision. Proponents of the bill, assuring their interrogators that no such legerdemain was intended, struggled to keep a straight face while explaining that there were two bills rather than one because pension legislation properly fell under the jurisdiction of one committee while taxing bills fell under the jurisdiction of another. ${ }^{\text {jat }}$

When the District Court of the United States for the District of Columbia granted the major railroads an injunction restraining collection of the tax in June of 1936 , ${ }^{1,44}$ it appeared that the Fuchs strategy had foundered. Citing extensivcly to the congressional debates, ${ }^{\text {tos }}$ the district court concluded that the Carrier Taxing Act and the Railroad Retirement Act were two parts of a single scheme that, taken as a whole, contained many of the defects from which the 1934 act had suffered. ${ }^{100}$

The Railroad Retirement Board immediately took an appeal. ${ }^{107}$ But in December of 1936, before the Court of Appeals could hear argument in the case, President Roosevelt suggested that railway management and labor get together and negotiate the terms of a railroad retirement act. Representatives of all of the major railway labor unions sat down with agents of al] of the major railroad companies, members of the Railroad Retirement Board, representatives of the Treasury Department and members of Congress. By the summer of 1937 an agreenent bad been reached, and its provisions bad been embodied in the Cantier Taxing Act of 1937, and the Railroad Retirement Act of $1937 . .^{108}$ Congressmen praised the process and the agreement as "a great tribute to the principle of collective bargaining." 109 Such collective bargaining in the railroad industry had been institutionalized by the Railway Labor Act of $1926,{ }^{110}$ which the Court had unanimously sustained in a 1930 opinion written by Hughes himself." Sponsors professed their faith that both the 1937 bills and the 1935 Acts were constitutional. ${ }^{12}$ Representative Clarence Lea added, however, that "Friends of this legisla tion, in my judgment, need not particularly fear ultimate Court disposal of this problem. "113 For; as Representative Carl Mapes explained, as part of the deal "It is agreed between the representatives of the railroads and the brotherhoods that they will nol contest the constitutionality of this legislation. , and that they will use their influence against having anyone else bring such action. ${ }^{+1 / 4}$ The parties were true to their words, ${ }^{1 / 3}$ and the retirement system they cre- 
ated remains with us in modified form to this day.

The strategy of the sponsors of the Carrier Taxing Act and the Railroad Retirement Act of 1935 was informed by the opinion of the Court in Frothingham yellon. ${ }^{\text {17 }}$ The case was actually decided in 1923, when William Howard Taft was Chief Justice. But a majority of the Justices who joined that unaninous opinion were also members of the Hughes Court. Mellon involved a constitutional challenge to the Sheppard-Towner Matemity Act of 1921." which established a federal grant-in-aid pro gram for the reduction of matemal and infant mortality. Under the statute, Congress appropriated funds to be disbursed to states that established qualifying programs for the promotion of matemal and infant health. Frothingham complained that the appropriations would in crease the burden of future federal taxation and thereby take her propery without due process of law. Justice Sutherland's opinion, joined by Justices Holmes, Brandeis, Van Devanter, Butler, and McReynolds, held that Frothingham's status as a taxpayer was insufficient to give her standing to challenge the appropriation. Her interest in the moneys of the federal treasury; he explained, was shared with millions of others, and was too "minute and indeterminable."

This "laxpayer standing doctrine" had enormous ramifications for federal spending policy in the 1930s. As Edward Corwin observed at the time, ${ }^{\text {"so }}$ long as Congress has the prudence to lay and collect taxes without specifyng the purposes to which the proceeds from any particular tax are to be devoted, it may contimue to approprate the national funds without judicial

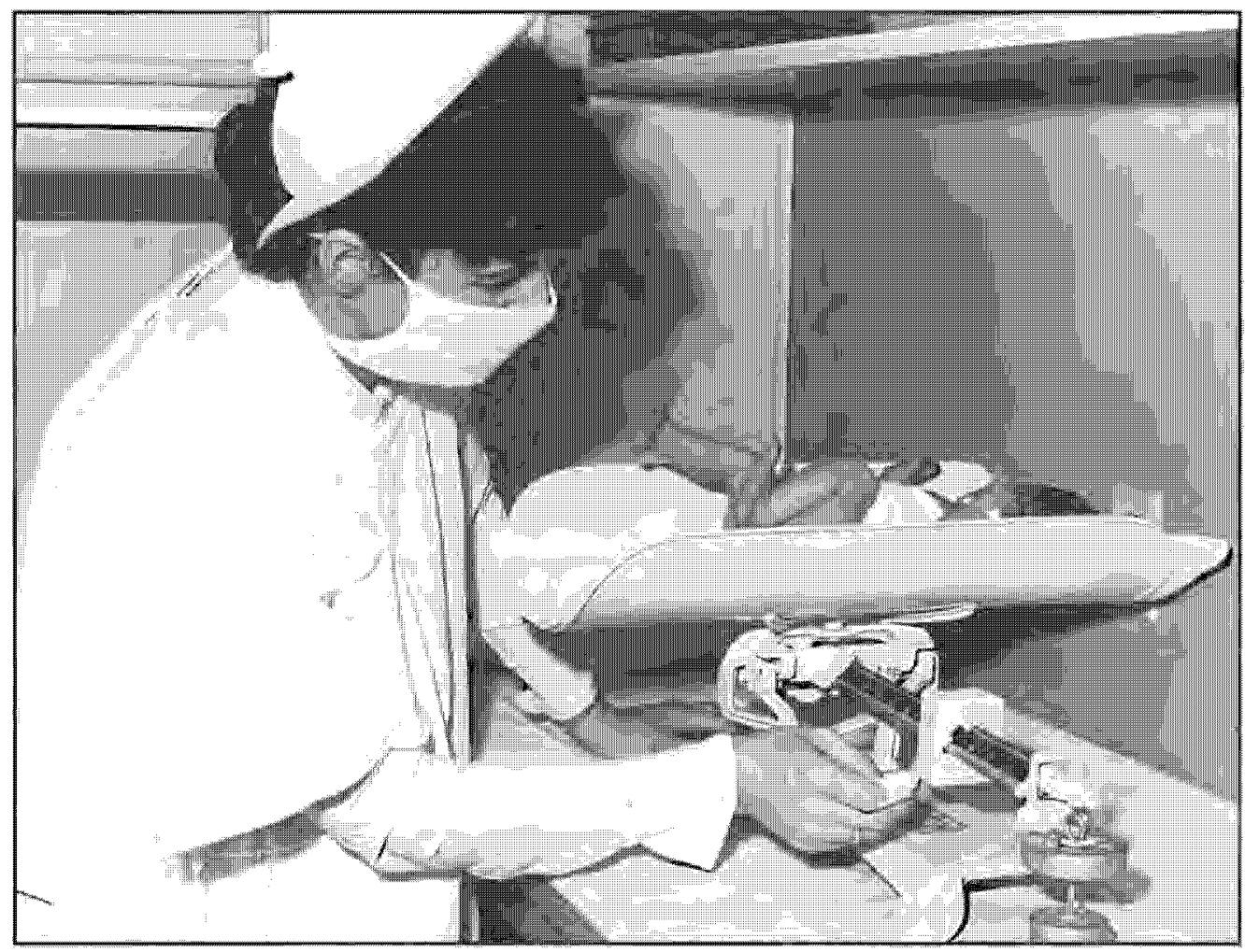

The Sheppard-Towner Maternily Aet ar 1921. which establisted a federal grat-in-aid program for

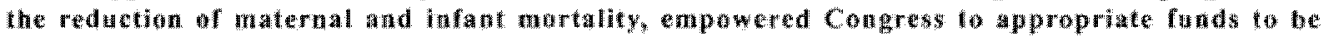

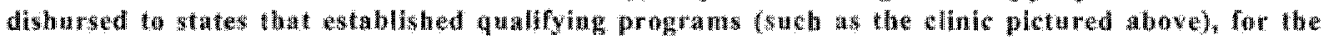
promotion of maternal and infant healk. A laxpayer complained that the appropriations wonld increase the burden of future lederal taxulion awd thereby take her property whout aue process of Iaw. The Court held that status a taxpayer was insurfictent to pive her standing to challenge the appropriatox. This "taxpayez standing doctrine" bad enowmous ramincations for" lederat spending polity un the 1930s. 
let or hindrance." Appropriations from the general revenue, as distinguished from expenditures of designated funds collected from a particular tax, simply could not be challenged in the courts. ${ }^{\text {21 }}$ Such an appropriation might exceed congressional authority to spend for the general welfare, but the federal courts would nevertheless refuse to restrain the expenditure. "Thus," wrote Benjamin Wright, "the spending of billions of dollars in civilian relief, and in the building of public works was beyond the

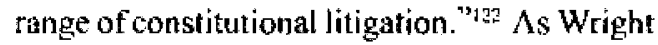
put it, "the principal way in which the Court sustained. . New Deal measures was by refusing to pass upon the validity of the spending power." ${ }^{2}: 3$

And Wright was right. Throughout Hughes' tenure, the Supreme Coust and the lower federal courts repeatedly invoked the Mellon doctrine in rejecting constitutional attacks on loans and grants made by one of the most popular and important New Deal. relief agencies, the Public Works Administration. ${ }^{124}$ Undoubtedly because the Mcllon doctrine posed such an insuperable obstacle to securing judicial review, a vast array of New Dead spending programs, all financed from general revenue, never underwent constitutional challenge during Hughes' tenure. Examples include the Civilian Conservation Corps. ${ }^{135}$ the Farm Credit Act ${ }^{\text {lat }}$ the Reconstruction Fitjance Corporation, ${ }^{127}$ the Rutal Electrification Administration $\Lambda c t,{ }^{128}$ and the Emergency Relief $\Lambda p$ propriation $\Lambda c t$ of $1936 .{ }^{129}$ Indeed, the most significant thing about the Hughes Court's much-discussed spending power jurisprudence is how little it actually mattered in light of the taxpayer standing doctrine.

One major New Deal spending initiative that the taxpayer standing doctrine did not shelter from judicial review was the Agricultural Adjustment $A c t$ of $1933^{136}$ In an effort to boost sagging crop prices resulting from chronic agricultural surpluses, the Act authorized the Secretary of Agriculture to enter into contracts witl individual farmers. In the contract, the farmer would agree to reduce his production of certain specified agricultural comınodities in exchange for a benefit payment. ${ }^{131}$ For political reasons, however, President Roosevelt opposed payment of the benefits from general rev- enues. ${ }^{132}$ He did not want it to appear that the nation's farmers were feeding at the public trough. Instead, he insisted that the progran be and appear to be self-financing. ${ }^{33}$ The necessary funds were therefore to be derived from a special excise tax on food processing. The tax was designed to generate the amount of revenue required to meet the benefit payments contracted for, and the act appropriated the proceeds of the tax for that purpose ${ }^{13+4}$ A food processor challenging the validity of the excise therefore had standing to question the propriety of the expendiure to which the proceeds of his tax payments were specifically devoted. ${ }^{35}$ And in United Siates $r$ Butler the Court struck down the tax as a step in a scheme to usurp the states' authority to regulate agrieultural production. ${ }^{137}$

But while the Buller opinion invalidated the processing tax the govemment continued to make the benefit payments for which it had contracted. With the processing tax no longer enforced, no one had standing to challenge the appropriations from general revenue by which the payments were now funded. ${ }^{13}$ Moreover. within two months of the Bwiler decision Congress enacted a statute to replace the $\triangle A A$. The Soil Conservation and Domestic Alloment Act of $1936^{139}$ authorized the Secretary of $\mathrm{Ag}$ riculture to pay farmers to shift acreage from soil-depleting crops to soil-conserving crops. It was not sheer coincidence that the soil-depleting crops were the very surplus commodities whose production the $A \wedge A$ had sought to control, while the soil-conserving crops were not overproduced. Five hundred million dollars were appropriated to fund the payments, but no companion taxing measure was enacted to provide the necessary revenue. Opponents of the measure complained that it was clearly unconstitutional in light of the Butler decision. But because there was no tax identified with the expenditure, no one had standing to challenge the constitutionality of the payments. ${ }^{140}$ ) Senator Daniel Hastings challenged defenders of the bill's constitutionality "to add to it a tax provision to supply the necessary money and thus give to the American people an early opportunity to test its validity. Do not do the cowardly thing and separate the tax provision front this bill, thus making it impossible to prevent 
the illegal spending of at least a half billion dollars." ${ }^{\text {MA1 }}$ But proponents of the bill, chastened by the fate of the AAA, ignored this schoolyard taunt, and the law was enacted and implemented in its unchallengeable form. ${ }^{142}$

As Robert Stem observed, however, the soil conservation strategy was "subject to the limitations of any voluntary system, even one in which cooperation was made profitable. There was no assurance that enough producers would cooperate to permit a limitation of production sufficient to raise prices." ${ }^{\text {143 }}$ Accordingly, in 1938 Congress tumed to a regulatory solution, enacting a second Agricultural Adjustment Act. The 1938 Act did not regulate the production of staple crops - instead, it authorized the Secretary of Agriculture to prescribe and allocate marketing quotas for those crops. $^{\text {14t }}$ Drawing on a long line of precedents holding that sales for subsequent shipments in interstate commetce were subject to federal regulation. Congress sought to control prices by controlling the supply of agriculnural produce moving in interstate commerce. ${ }^{1+5}$ But where could federal legistators have gotten the idea that Congress might achieve through its commerce power what it could not aftain using its fiscal powers?

These are the opening lines of Roberts' discussion of the issue of federal power in Butler.

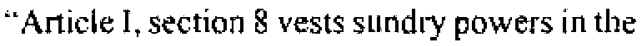
Congress," he wrote. "But two of its clauses have any bearing upon the validity of the statute under review." The first was the Commerce Clause. But, as Roberts observed, "the act under review does not purport to regulate transactions in intcrstate or foreign commerce. lts stated purpose is the control of agricultural production, a purely local activity. ... Indeed, the Government does not attempt to uphold the validity of the act on the basis of the commerce clause, which, for the purpose of the present case, may be put aside as irrelevant. "1/4/3

This was a curious passage. The act did not purport to be an exercise of the power to coin money or to establish post offices either; nor did the government defend the act as exercises of those powers. Why, if he was to so quickly tay it aside as inapposite "for the purpose of the present case," did Roberts even bother to mention the commerce power?
Learned students of the Court's federalism jurisprudence thought they detected a farniliar signal. In 1921 Congress had sought to use its fiscal powers to regulate sales of grain futures on boards of trade. The Future Trading Act ${ }^{14 T}$ imposed a prohibitive tax on all such sales, and then exempted from the tax all sales made on boards of trade complying with federal regulations. The Court had declared the Act unconstitutional in Hill v. Wallace $e^{148}$ in 1922. Chief Justice Taft's opinion for a unanimous Court held that the Act imposed a regulatory penalty rather than a true tax, and was accordingly not a valid exercise of the taxing power. ${ }^{149}$ In dicta, however, Taft had offered Congress an alternative means of achieving its goal. Noting that Congress "did not have the exercise of its power under the commerce clause in mind and so did not introduce into the act the limitations which certainly would accompany and mark an exercise" of that power, Taft suggested that sales of grain futures might be regulated under the commerce power if "they are regarded by Congress, from the evidence before it, as directly interfering with interstate commerce so as to be an obstruction or a burden thereon." 150 Taft even hinted that the revised statute be based on the current of commerce doctrine ${ }^{|s|}$ the Court had employed in uphoking the Packers and Stockyards Act ${ }^{152}$ earlier in the Tem. ${ }^{153} \mathrm{Con}-$ gress took the hint and enacted the Grain Futures $\mathrm{Act}_{3}{ }^{154}$ which the Court upheld as a legitimate exercise of the commerce power the following year in Chicago Board of Trade $v$ Olsen. ${ }^{155}$

Senator James Pope of Idalo, the principal sponsor of the Agricultural Adjustment Act of 1938, drew attention to this passage from Roberts' Buller opinion in his defense of the 1938 Act's constitutionality. "The legal theory on which the pending bill is based is entirely distinct from that which provided the basis for the Agricultural Adjustment Act," Pope explained ${ }^{156}$ Asserting the need to make the Act's constitutional foundation in the Commerce Clause explicit in the preamble, Pope observed that in Buller "the Court said by reason of the fact that there was no statement or claim in that bill that we were proposing to regulate interstate commerce, it was a purely local transaction. "157 "As stated by Mr. Justice Roberts." 


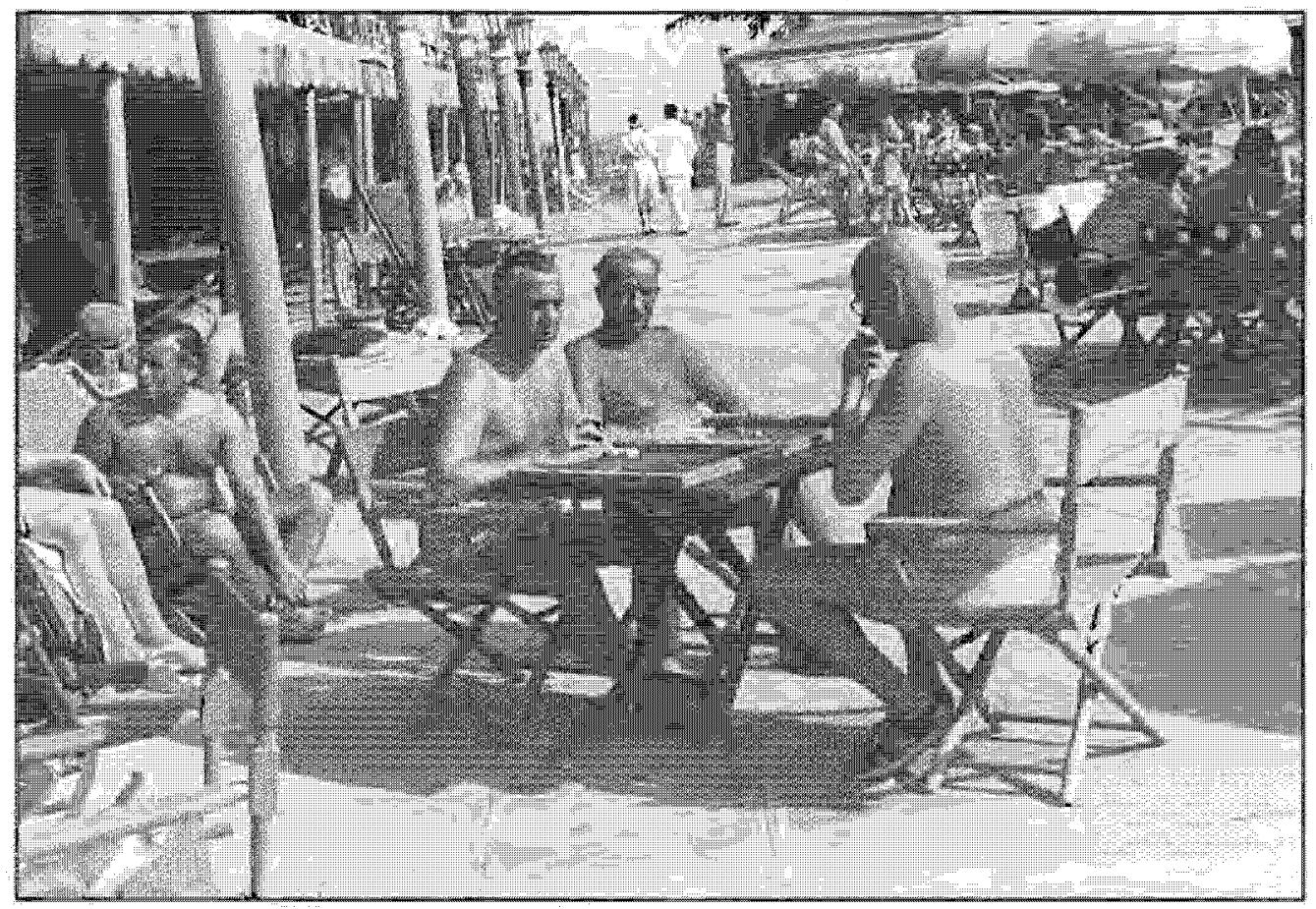

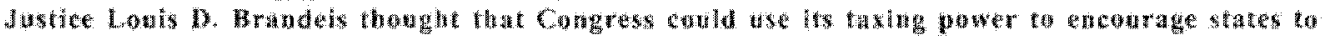
enact unemployment compensalion laws by drawing on the authority of Florida v, Mellon. In that

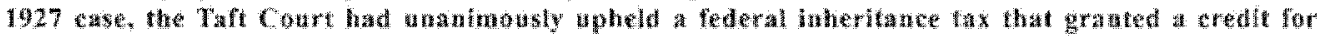

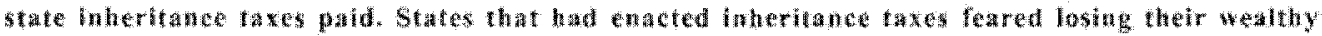
residents to stakes Ithe Florda that had no such taxes, and the federal provision bud been designed to level the prayimg rinete.

Pope continued, "the commerce clause of the Constitution was putaside as irrelevant in the Buter. . decision. Interstate and foreign commerce, however, is certanly not irrelevant to the plight of agriculture at the present time, and through the proper regulation by Congress of ...interstate and foreign commerce pursuant to the provisions of this bill the economic situation of the farmer ean be set aside." "ists

Solicitor General Robert H. Jackson, defending the Act before the Court in Mulford $v$. Smith, ${ }^{\text {s. }}$ drew the obvious analogy to the fate of grain futures regulation under Taft, "Tt is clear from HWh Wallace and Chicago Boald of Trade v. Olsen:" he wrote in his brief, "that Congress may utilize the commeree power to regulate subjects which it may not reach under the taxing power. ${ }^{* 1 \text { (1) }}$ True to form, Roberts used his opinion in Mufford to replicate Taft's performance in Chicago Bound of Thade $v$ Olsen: he upheld the Act as a valid regulation of interstate commerce. Two yeass later Jackson wrote in The Struggle for Judicial Supremacy that "the decision was followed by a good deal of uninformed comment to the effect that $\mathrm{Mr}$. Justice Roberts had reversed his position and that the Court had reversed itself on the subject of control of agricultural production by the Federat Govermment." "This," the astute Jackson insisted, "was cerainly untrue." "it

1 would be remiss if I did not relate one final instance of constitutional consultation. Irefer to what is now the familiar story of Justice Brandes" role in framing the uneruployment compensation provisions of the Social Security Act. In the summer of 1933 Brandeis was visited at his vacation cottage by his daughter, Elizabeth Brandeis Raushenbush, and her husband, Paul. Both were economists at the University of Wisconsin, and deeply interested in the subject of unemployment insurance. Paul expressed to the Justice his frustration that the states had resisted enacting statutes on the subject because they were fearful that local businesses would be placed at a competitive disadvantage vis-a -vis businesses of states not 
having such laws. Brandeis replied by asking whether Paul had considered the case of Florida 1 Mellon ${ }^{103}$ In that case the Taft Court had unaninously upheld a federal inheritance tax that granted a credit for state inheritance taxes paid. States that had enacted inheritance taxes feared losing their wealthy residents to states like Florida that hat no such taxes, and the federal provision had been designed to level the playing field. Brandeis was suggesting that Congress could similarly use its taxing power to encourage states to enact unemployment compensation laws. Congress could simply impose a uniforn national payroll tax on all employers. the proceeds to be paid into a federal unemployment insurance fund. Employers would be allowed a credit against the federal tax for any amount paid into a comparable insurance plan established by their own states. States could then enact such insurance plans free of the concents that had previously restrained them.

That September the Justice wrote Paul and Elizabeth a letter detailing his proposal for a federal unemployment compensation statute. Throughout the fall of 1933 Brandeis personally lobbied a number of high administration officiats to support his plan. ${ }^{\text {is }}$ At the same time he had his friend Lincoln Filene help Paul and Elizabeth organize a meeting of the influential to discuss his proposal. Among those in attendance was Secretary of Labor Frances Perkins. ${ }^{165}$ Perkins commissioned Paul Raushenbusl and Thomas Eliot to draft a bill based on Brandeis' proposal. When it had been introduced in the House and the Senate, Brandeis referted to the bill as "my federal excise tax. . . to offset irregularity of employment." "is

As the bill ran into resistance in Congress and the White House, Elizabeth served as the Justice's eyes, ears, and chief lieutenant, lobbying the administration and recruiting opinion leaders to support the Brandeis proposal. ${ }^{167}$ The I ustice conscripted Felix Frankfurter to aid her in the crusade for the "one true faith," and met personally with Edwin Witte, the Executive Director of Secretary Perkins' Committec on Economic Security, in an effort to win him over. Brandeis even extended his evangelism to the Oval Office-he and Roosevelt had a personal conference in which Brandeis made the case for his scheme of federal-state cooperation. ${ }^{16 *}$

The bill that ultimately energed gave Brandeis most of what he had wanted. His early initiative had framed the debate, and his position on the Court gave special weight to his counsel. ${ }^{169}$ This counsel was vindicated in the spring of 1937. when the Court sustained the Act against constitutional challenge. ${ }^{12}$ Figuring prominently in Justice Cardozo's majority opirtion was the case of Florida เ. Mellon. "

While Justices McReynolds and Butler maintained in dissent that any such program was beyond congressional power to enact, ${ }^{1 / 2}$ the author of Florida $v$. Mellon wrote separately. ${ }^{17 t}$ Justice Sutherland had decided to retire from the Bench in March of 1937, and was waiting only for the Court-packing controversy to subside before taking his leave. ${ }^{17.1}$ His colJeague Justice Van Devanter had announced his retirement May 18, six days before the Social Security Act opinions were delivered. ${ }^{175}$ Under these circumstances, one might liave expected these Justices to quietly join the dissent of their fellow Horsenen, Instead they fashioned a dissent that provided precisely the sot of consultation that Hughes had called for in his own dissent in the railway pension case. Sutherland began by anouncing that he agreed with most of what was said in the majority opinion. ${ }^{176}$ In fact, the only element of the scheme to which Sutherland objected was a provision that reguired the states to pay the proceeds from their own payroll taxes into the federal treasury, and allowed witldrawals only by state agencies approved by the federal bond. Such a requirement. in Sutherland's view, did not "comport with the dignity of a yuasi-sovereign state;" "In but the objectionable provision might also be easily revised by Congress, Sutherland explained. Indeed, he maintained that "everything which the act seeks to accomplish for the relief of unemployment might have been accomplished. . . without obliging the state to surrender, or to share with another government, any of its powers." As Sutherland pointed out, the Social Security Act's old-age pension provisions had accomplished their goal in a manner consistent with the Constinution, and he and Van Devanter joined the opinion upholding them that very day. ${ }^{179}$ Make one rela- 
tively minor reviston in the unemployment compensation provisions of the statute, their dissent made clear, and there would have been seven votes to uphold them as well.

That same day Justice Stone wrote the majority opinion upholding Alabana's state unemployment compensation act. McReynolds simply dissented without opinion. ${ }^{\text {" }}{ }^{3}$ But Sutherland, this time joined by both Van Devanter and Butler, again dissented separately. "The objective sought by the Alabama statute here in question, namely, the relief of unem. ployment, ldo not doubt is one within the constitutional power of the state," Sutherland began. "But it is an objective which must be attained by legislation which does not violate the due process ot the equal protection clause of the Fourteenth Amendment. This stante, in my opinion, does both, although it would have been a comparatively simple matter for the legislature to avoid both." After detailing the ways in which the act denied due process and equal protection, Sutherland observed that "other states have not found it mpossible to adjust their unemployment laws to meet the constitutional difficulties thus presented by the Alabama act. The pioneer among these states is Wisconsin." of course, neither Wisconsin's nor any other state"s unemployment act was before the Court. Sutherland nevertheless went on to explain the provisions of Wisconsin's statute, iss and to offer an advisory opinion on its constitutionality. "I entertain no doubt that the Wisconsin plan is so fair, reasonable and just," be wrote, "as to make plain its constitutional validity, "Even in dissent at the end of their careers, Sutherland and Van Devanter wera of ering pointers on how to at tain permissible ends through means consistent with the Constitution. Incidentally, the Wisconsin statute the dissenters praised had also been arafied by Paul Raushenbush. And that draft was based on a memorandum written in 1911 by an extraordinarily able constitutional lawyer: Louis D. Brandeis. $18 \%$

In March of 1937, at the height of the Courtpacking struggle, Chief Justice Hughes was visited at his home by Senator Burton $K$. Wheeler. During that conversation Hughes wondered aloud whether the constiutional his-

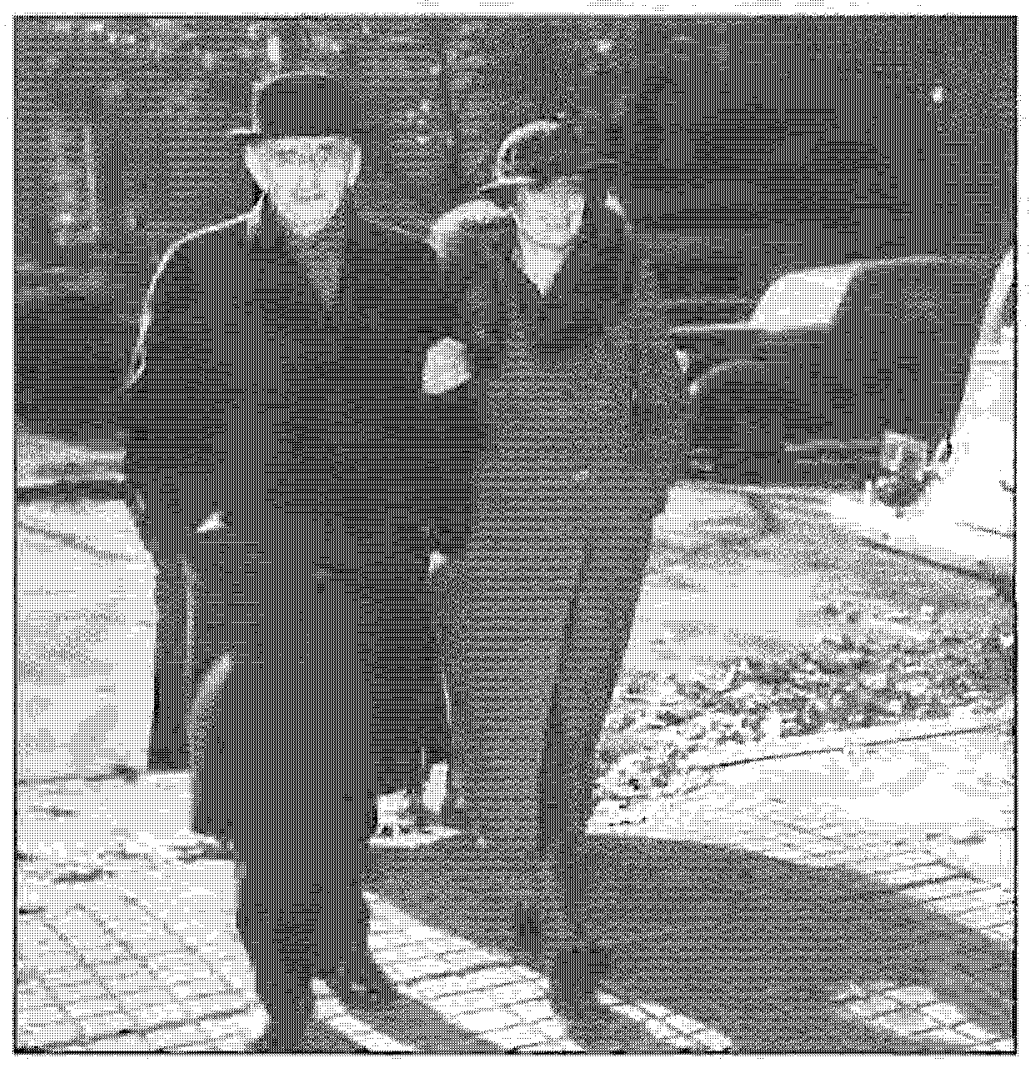

Justice Brandeis calisted lis datagleter. Elizaber Erandeis Rashenbush, and her husband, rats. bouh economists at the Uniwersity of Wisconsin and both a ceply antertested in the shbject of unenphay

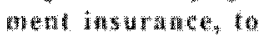
belp him shape the unemployment provisions of the Sorial Security art. 4s the bill encountened appostton, cluabeth ser vad ats the Justices cyes, cars, and chier litutenant lobbying the adinumistration and rectuitury opinon leaders to support the bill, Here whe is pictured with har rather on his exglteth birthday. Noveruber 1, 1936. 
tory of the New Deal would have been different had Roosevelt appointed a different Attorney General. Remarking that "the laws have been poorly drafted," Hughes told Wheeler, "We've had to be not only the Court but we've had to do the work that should have been done by the Attomey General." 189 Hughes might have been referring to any of a number of failures on the part of the Justice Department, but one was almost certainly on his mind. That very month Congress was framing the Bituminous Coal Act that Hughes and his Cour would ultimately uphold. In 1935 a subcommittee of the House Ways and Means Committee had asked Attomey General Homer Cummings to appear and offer his views concerning the Guffey Coal Act's constitutionality. ${ }^{199}$ Lawyers in his Justice Department had been convinced that the labor provisions were unconstitutional, ${ }^{190}$ and had reportedly told him so before his appearance. ${ }^{191}$ But Cummings had refused to offer Congress an opinion on the bill's constitutionality. Instead he had advised the subcommittee "to push [the bill] through and leave the question to the courts." 192 For Hughes, this episode was no doubt emblematic of the early New Deal. In his eyes, the Attomey General's office had not given the administration and Congress the constintional counsel they needed, but had left that important task to the Court instead. In his State of the Union address in January of 1937, Roosevelt had said, "The judicial branch . . . also is asked by the people to do its part in making democracy successful." ${ }^{\text {mol }}$ In Hughes" view, the judicial branch had been doing its part and more.

Every first year law student learns that constitutional law is not only about the permissible ends of government; it is also about the means by which such ends may be attained. Yet our conventional renderings of the Hughes Court obscure this important distinction, portraying the constitutional disputes of the New Deal era as disagrements principally about ends. In suppressing this elementary distinction between the legitimate objectives of govemment and the manner in which those objectives may be achieved, we have lost sight of the distinctively consultative cole played by the Court during Hughes" unique tenure. If we will ondy remember what we have al ways known, and what so many in the Congress of the $1930 \mathrm{~s}$ clearly understood, we will see that the Supreme Court under the chief justiceship of Charles Evans Hughes faced the economic and political crises of the 1930s neither on four feet nor on three, but instead firmly on two.

* Thanks to Jason Tilly and Greg Kratofil for excellent research assistance.

\section{Endnotes}

'Joseph Alsop \& Turner Calledge, The 168 Days 16, I55 (1938); Leonard Baker, Back to Back: The Duel Between F.D.R. and the Supreme Court 110 \{1967\}; Merlo J.Pusey, Charles Evans Hughes 73$\}$ (1951): Burton K. Whaeler. Yankee From the West $330(1962)$.

See William R. Gasto, The Supreme Court in the Early Republle 77-8) (1995).

Wheler, supra note I, at 330 .

Alsop \& Calledge, supra note 1, at 16.

"Id. For the suggestion of one New Dealer that the Count ought to be required to give Congress advisory opinions, see remarks of Rap. Monaghan, 79 Cong Rec. $7150,74^{\text {th }}$ Cong. 1" Sess. (May 8,1935 ).

"F. Carlisle Roberts, "The New Frazier-Lemke ActIIs Provisions, Its Corstututionality," 22 A.B.A. J. 15 (1936). See, eg., John Hanna, "Agriculture and the Bankruptey Act," 19 Mimn. L. Rev. I, 28-32 (1934) John F. Reinhard", "The New Frazier-Lemke Amendment," 4 Kan. Cin R. Rev 19 (1935); R. O. Williams. "The Frazier-Lemke Law," I3 Neb. L. B. 481, 490-91 \{1935); Note, "Bankruptcy: Federal Farm Mortgage Relief under the Bankrupley Act," 21 Corn. L. Rev. $171,171-72$ (1935). For predictions that the first Act would be held unconstimutional, see, e.g. Note, "Relief of Distressed Farmers Under the Frazier-Lemke Acl?" 3 G.W L Rev 86, 95-96 (1934); Note, "BankruptcyValidity of Frazier-Lemke Ael," 29 III. L. Rev. 645, 653 (1935). John Hanna, "The Frazier-Lemke Amendments to Section 75 of the Bankruptcy Act," 20 A.B.A. J. 687, 689 (1934) and Reuben G. Hunt, "Land Titles as Affected by Bankruptey," 20 A.B.A. $f$ 719,722 (1934), suggested the Acl's constitutionality was open to scrious question.

Roberts, sipra nole 6 .

" "Bankruptcy: Federal Farm Mortgage Relicf under the Bankrupley Act," slipra note 6, at 173

"Relief of Distressed Farmers Under the FrazierLenke Act?," supra note 6 , al 87

"The Frazier-Lemke Amendments to Section 75 of the Bankruptcy Act," sapra note 6, at 689. See also, Roberts supra note 6 , at 15 ("an outstanding example of ill-conceived legislation" $)$.

"Relief of Dislressed Farmers Under the FrazicrLemke Act?" supra nole 6. al 87. Sé also "Bankruplcy: Federal Farm Mortgage Relief under the Bankruptey Act," supra note 6, at 174

"Relief ot" Distressed Farmers Under the Fraziet-Lemke Act?" supra note 6 , at 87 .

Id. 
14 "Bankuptcy: Federal Fann Mortgage Relief Under the Bankriplcy Acl, "supra note 6, at 173

The New' York Tiwes, July 1, 1934, at 21, quoted in "Bankruptcy: Federal Farn Mortgaga Kelief Linder the Bankruptcy Act," supra note 6. at 173, a 22, See Note, "The Naw Frazier-Lemke Act: A Study." 37 Colum. L. Rev. 1092, 1094 (1937).

295 Li.S. 555 (1935).

See Lewis J. Paper, Brandeis 350 (1983); Melvin 1. Hrofsky, Louis D. Brandeis and the Progressive Trudition 162 (Oscar Handlin ed., 1981).

Those were:

"I. 'The right to retain the bien until the indebtedmess thereby secured is paid.

2. The right to realize upon the security by a juticial public sale.

3. The right lo determine when such sale shall be hetd, subject only to the discretion of the court.

4. The riglit to protect its [the mortgagee's] inlerest in the property by bidding at such sale whenever held, and thus to assure having the morigaged property devoted primarily to the satisfaction of the debt. either through receipl of the proceeds of a fair competitive sule or by taking the property itsetf.

5. The right to conlrol meanwhile the property during the period of default, subjeci only to the discrelion of the court, and to lave the rents and profits collected by a receiver for the satisfection of the delu." 295 U.S. at $594-95$.

"Bankrupccy: Federa! Farm Mortgage Rẹlief under the Bankruptcy Act," supra note 6 al 173.

Richard D. Finedman. Charles Evans Hugles as Chief Justice, 1930-1941: The Complexities of Moderation 231 (uopublished D. Phil. diss, Oxford Uiniversity, 1978).

See "The New Frazier-Lenke Act: A Study," supru note 15 , at $1095-96$.

S. 3002,74 cong. $i^{\text {st }}$ Sess. (1935) was introduced June 5, 1935, 79 Cong Rec. 8666, 74 Cong. Is Sess. (1935); 5. Rep. Kio. 985, 74t Cong. Is Sess (1915) Was submitled buly I, 1935.79 Cong. Rec. I0463. A comparable bill. H. R. $8728,74^{\text {k }}$ Cong. 1 Sess. (1935) was introduced in the Houre June 29, 79 Corg. Rec. 10458, and reported with anendments Augus! 16, 1935 , H. Rep. No. $18087^{\text {th }}$ Cong. 1 $^{\text {t1 Sess. }} 79$ Cong Rec. 13494, H.R. 8728 was tabled and the Senate bill, as amended, was passed in lieu thereof. 79 Cong. Rec. 14334. The Senate subsequently concurred in the House amendments. $d d$. at 13233-14.

"Bankruptey: Federal Farm Mortgage Relief under the Bankruptcy Ac1." sutpra note 6. at 173-74.

William A. Reppy. Comment, "Constintional LawBankraptey-Frazier-Lemke Amendment," in So. Cal. L. Rev 474, 476 (1937). See also Roberts, supro note 6. "The cotsititutionality of this Act, bectuss of the fate of its predecessor. was the paramount consideration during its prouress through Congress," one commertatur pointed oul. "Bankruptey: Federal Farm Relief Under the Bankrupley Acl," supra nole 6, at 176. The new Ac1 was passed "after exlensive hearings." Rohers supra nole 6 , at 15 , and "[l] Ju Judiciary Committed of the Senate. , including some of the most able lawyers in the upper house on constitutional questions, was unanimously in favor of the bill." "Bank- ruplcy: Federal Farm Relief Under the Bankruptcy Act," supra note 6 , at 176 , n. 39. The report of the Senate Judiciany Committe began by statng that "This bill has for als abject. . the rewriting of subsection(s). which has been hetd uncongridutional, so as to conForm to the decision of the Supreme Court." $S$. Kep. No. 985, 74 Cong. $1^{\text {th }}$ Sess.. at 1 (1935) "We feel that all the provisions in the rewritten subsection(s) have been approved in principle in numerous decisions by the Supreme Court." Id. a1 3. The balance of the report delailed how nbjectionable provisions had boen either omitted entirely. id at 4 , or modified so as to sesemble provisions that the Supreme Cour had prewously approved in other bankruplcy cases, $7 d$. at 5,

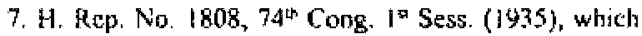
accompanied H.R. 8728, 74 Cong. It Sess. (1935), the House version of the bill, was virtually identical to the Senate report

Asked by Senator McKellar whether the Judiciary Comutute was satistied that the bill would pass constitutional muster, Senalor Pat McCarran assured him, "*i can only aflim our fäth in its constinutionalily. , We sought, and the authur of the bilt sought, to relieve the bill of lhose provisyons which had been declared to be unconstitutional by the Supreme Court . . - if any bill can be enacted which will be constitutional il will be a bill along thesse particular lines, . . The committer has studied the qucstion caretully, and has inserled in the bill a number of amendments seeking to have it conform to what we believe to be constitutional recuirements. . . . I believe wo have obvated the feateres which might verge upor unconstitutionality" 74 Cong. Rec. 11971, 74 Cong.

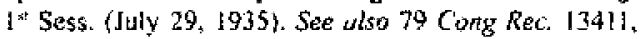

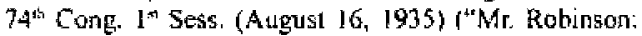
The pending bitl is intended to cortect the fearures of that act which were held to be unconsticutional" $\mathrm{l}_{1}^{\text {a }} \mathrm{id}$. ("Mr. Borah: The pending bitl is designed to, and it is believed it does, avoid the unconstimutional teatures which were in that law"): id st 13632 ("Mr. Borah: The pupose of the bill is to awoid the objectionable fatures of the former act as they were denounced by the Sugreme Court." Borah then ex. plained how the riew bit 1 did so); id. at 363 (Sen. Borald and Sen. Frazier explaiti to Sen. Hastings, to Hastings' Salisfaction, why discretion vested in the court to order a sale of the property tearlier than 3 years from line date of banknuptcy rescued the Act fiom a constitutional difficulty that plagued the earlier act; $a$. at 13640 (Sen. Robinson concurs in Borah's and Frazier's explanation to Hastings)' $i d$. at 1383 1 "Mr. Lloyd: Mr. Speaker, this is a bill that has been rewritten by the Committee on the Judiciary as a substitute for the bill that the Supreme Court declared unconstimtional. The commite thas given very carefil consideration to the bill. We have in no way reduced the security of the mortgagee. We have left his security intact, but we have made it possible for the bankruptcy courr to retain jurisdiction for a period not to exced 3 years. It is the feeling of the commitlee that if the fanners have a brcalhing spell they will be able to work out their own salvation. The bill we passed lasi year wis declared unconstitutional on the ground that il impaired the security of the mortgagee"li id at 1433 , "Mr. Lemke: All this bill goes is to comply with the decision of the Supreme Cutrt gring the fomer ho opportunily to get a breathing spell afier he goes into bankruptey ${ }^{\circ}$; id. al $14332{ }^{11} \mathrm{Mr}$. Greever: Does 
the gentlemar feel that the constintional feature that was decided by the Suprene Cour is now fully cured? $\mathrm{Mr}$. Cenke: I agree with the members of the Senale Judiciary Committe that, with the amendment that Mr. Sumners will offer, there will be no constitutional question about the bili.

Mr. Kloeb: . is the gentleman now satisfied in lits own mind that thus bill will pass the contitutional lest? Mr. lenke: Yes; I am salisfied that this bill now complies with the language of the Supreme Court desision. . . We have complied with the deciston. . "); id at 14333 " Mr. McCormack: It is the gentleman's opinion that this bill as now drafted comes within the constitutional powers of the Congress? Mr Sumners As I explained, that opinion is drawn largely from the unanimous opinion of the members of the Commiltee on the Judiciary, who have more carefuly examined it, but from the examination which i have made, which is rather casual, I did nor observe anything, if this amendment is adopted, which woukd make me apprehensive as to its constitutionality"), See Note, "Bankruptcy The Frazier-Iterake Acl," 22 Va. L. Rev. 218, 219 (1935).

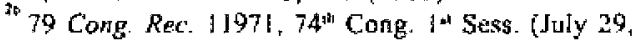
1935). Ashurst added, "l emphasize the fact that the Judiciary Commitec examined many aulhorities, and the commitlee carefully sonsidered this bill. . . . I believe the learled members of the Judiciary Comminlee have dome a good work on this bill. If it be within the power of congress to pass a law upon the subject, 1 belizve this bill will meet the objections of the Supreme Court. . . if Congress can constitutionally pass such a law al all it would be santilac to this one," $d d$

"Asked by Senator Copeland whether "this butl, in the forn in whish it is now presented to us, is likely to nut the gauntel of the courts and to be declared valid legistation?" Senator Borah responded that "that was the conclusion which was reached by the fudiciary Cormmittec, including myself. The Judiciary Commitle devoted their effort to working out the measure so as to bring it within the constitution and ohviate the ibjuctions made by the Court to the previous act I do nol think there was any disagreement in the judiciary Committe that we had finally fomed such a measure. It is my opinion shat it will rum the ga[u]rtlet of the courts . . in my opinion, this bill is constitutional." Copeland then asked Boab whether lie had taken "an opposite wiew regarding the original Frazier-lemke Act?" Borah responded that he had "opposed that measure hare on the floor, as the RECORD will show. . For the reason that I thoughr it was unconstitutional." Copeland replied. "A1 least, though, it appealed to the Senator's heart and he would have been glad to support it if he lyad thought it to be colystiou. tional"?" To this Borah responded: "I would have been Braxious to see the measure passed if I had thought it would have been able 10 escape the constulutional objection " $/ d$ at at 1364 ?

Several Senalors objecled to a provision in the Senate bill that would have limited the right of the mortgagee to bid on the property at auclion on the grourd that it would invalidate this measure if it were rewined." $M$ at 13634 (objection of Sen. Robinson); sere also id. a1 13413 (objeclion of Sen. Robinson); id al
13632-.73 (objections of Sen. Robunson and Sen. T.ogan); id. al 1364 (objeclion of Sen. Tydings). Sengtor Frazier was way ahead of them, and announced his intention to ofler an antendment striking the objeclionable provision, which had ajready been removed from the House version by the House Judiciary Cornmittee. Senator Borah concurred, saying "I do not wish to urge it [the provision objected to], if it be regarded of doubteul validity, ${ }^{2 x}$ id. at 13633 , and the bbjectionable provision was excised by amendnent. id. al 13643-44. Set also id. (Borah and Ashurst assure Logan that the objectionable proviston will be taken out of the bill); id. at 13641 ABorah informs Tydings of the agreement to strike the provisionl. Senalor Robinson also objected to proposed "provision wheh 1 think will cause the raising of another constitutuonal guestion on this bill" and woutd "endanger the validity of the proposed act." Id. al 13641. See atso id at I 3634-36, 13640-4I. Senator Ashurst agreed to its exclusion, and the amendment that would have included the objectionable provision was defeated. Id. at 13643. In the Houge Representalive Sunvers sought further to secure the Atr's constitutional foundation, oftering an amiendment, promptly agreed to securing to the mortgagee the right to have foreclosure on the property if the debt was not paid in full. Id' at $14.732-$ 33

When the bill was introduced in the House, congressman l.emke announced, "This bill was very carefully considered by a subcomnitlee of the Committee on tise Judiciary of both the House and the Senale, and by the full Commitree on the Juticiary of both the Ifouse and the Senate, and last Monday it was passed after an hour and a half discussion on the question of its constitutionatty, without a dissenting vote, in the Linited Stales Senate." $r d$. at 14332. In a concluding defense of the bill's constitutionality Sumners maintained thal "allhough there was doubt with reference to the firs bil][.] I understand from my colleagues on the commitlee there is not now any doubl as to the conslitulionality of this bull. ...." id. at 14337. The bill was then passed by a voice rote. The Cornell Law Review observed that "the tack of ppposition in both ehambers seams to indicate thal the legislators were satisfied with the present $\mathrm{Act}_{\text {, }}$ and that "the consensus of Congressional opinion seems to be that the rights of the creditor have been fully protected.

"Bankniptey: Federal Farm Mortgage Relief Under the Bankruptey Act," supra note 6, at 174, 176.

"Comment. "Constitutional Law-Fifth Amendment-Invalidity of Frazier-I emke A mendment to the Bankruptcy Act." 35 Colum. L. Rew 1136,1138 (1935). Reaching the same conclusion were Note, "Consitutionalily of the New Frazier-Lemke Amend. neet to the Bankruplay Act." 4 C.W. L. Res 105, 1.4 (1935): "Bankruptcy: Federal Farm Mortgage Relief Under the Bankruptcy Act, stapra note 6 , at 171 . 176; Rufus K, Breihan, "The New Frazuer-Lemke Anendment," 41 Com. L. J. 152 (1936), Note. "Conslitutional I aw-Due Process-Validity of Amended Frarier-i.emke Amendment to Bankruptcy Acl." git C. Pa. L. Rev. 545, 546-47 (1936).

Not all commentators were so optimistic bee. e.g. Roberts, supra note 6; Note, "Constitulional 
Law-Bankuptcy - Validity of Amended Frazjer-Lemke Farm Morgage Moratorium Law," I3 N.Y.U. L. Q. 465 (1936), John Hanna, "New Frazier-Lenke Act," I Mo L. Rev: I (1936); Reinhard, stupro note 6, at 21, 29.

The majority of the lower federal courts hearing chatlenges to the revised act hold it unconstimtional. See Comment, "Constintional L.aw-Bankruptcy-Frazier-Lemke Amendmen1," t0 So. Cal. L. Rev 474, 476 (1937). For comments criticizing these decisions as resting on a misunderstanding of the Rodford opinion, see Note. "Constitutional I.aw-Due Process Validity of Amended Frazier-Lemke Amendment to Bankruptey Act, $84 U$. $p_{a}$. L. Rev 545, 546 (1936); Note, "Bankruptey-FrazierLemke Acl-Due Process-Full Faith and Credit," $4 G$. W. L. Rev 525, 526 (1936); Note, "Bankrtplcy-Constiutionality of the New Frazier-Lenke Act," $30 \mathrm{MI}$. L. Kes. 794, 795 (1936); "The New Frazier-Lemke Act: A Sttdy," supra note 15, ak 1096; Note, "Constinitional Law" - Due Process and the Frazier-Lenike Acts" 35 Mich C. Rev. $1130.1134-35$ (1937). See also Wright v Vinton Brouch Bank, 300 UI S. 440,457 (1937).

i) 300 U.S. 440 (1937).

Btief on Behalf of Rober Page Wright, p. 2. "When. the Supreme Court held the original Frazier-Lemke

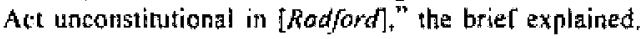

the present act was introduced in both the Senate and the House. It was referred to the Sudiciary Committees of the Senate and the House and both of these Committes referred it to Subcomnittees for study and consideration with the pupose of complying with the court's decision.

The author of the bill was called in by both of the Subcommittees. The Act was then carefully considered sentence by sentence, section by section, with the decision of the Supreme Court so as to comply with that decision. Many changes were made by the Subcommittes.

After the Subcommitres had finished their work the bill was reintroduced with the changes and amendments made by the Subcommittees and then was brought up before the Committees of the Whole of both the Serate and the House. Thore again the bill was gone over sentence by sentence, paragraph by paragraph and section by section carefuly considered and compared with the decision of the Supreme Cour, and turther amendments made.

The bill was then brought up on the fuor of the Senate and the House and further debated with a view of having it comply with the decision of the Supreme Court and was finally passed. . . without a dissenting vole in cither Housc.

dd. at 9 (emphasis in original). This thome was again emphasized at orat argument, 300 Li.S. at 443 . See "Constitutional Law-Due Process and the FrazicrLemke Acts," supra note 30, al 1136 n.31.

Brief on Behalf of Robert Page Wright, at $\mathbf{j - 6}$.

"Id. at 10-11. At argument Wright's counsel main- tained: "There is nothing novel in the new Ac1. It simply appties well estublished principles of bankruptcy Iaw to agriculture. This may appeser novel, but there is no provision of the Act which the banknprey cours have not already passed upon." 300 U.S. al 443.

Compare the Brief in Response to Petition for Writ of Certiorari, al II: "Respondent respecifully submits that a study of the presert act, and of the opinion of this Honorable Court in the Radford case. and of the first Frazier-Lemke Act, that was by that case held unconstitutional, will disclose a studied effort by the draftsmen of the present act to give an appearance of compliance with the Radford decision, while at the same time it takes away from the creditor the same substantive right in specific property that was illegally to be accomplished by the first Frazier-Lenke Act."

300 U.S at $456-57$.

id at 464 n.9.

Id. at 458 n.2.

Is. at 470 .

${ }^{19}$ West Cops Hold Co v. Parish, 100 U. 5.39 (1937)

NLRB : Friadman-Hary Marks Clothing Co. 301

U.S. 58 (1937); NLRB v Frwehan Trailer Co, 101 U.S. 49 (1937); $N L R B$ v , Whes of Loughtin Sled Corp. 30 L U.S. I (1937).

Sleward Mach, Co. watis, 30 U.S 548 (1937); Camichad $v$ Sowhern Coal a Coke Co, $301 \mathrm{U}, \mathrm{S}$. $495(1937)$.

"Comment, "Constitutiona] [,aw-Frazier-Lemke Act-Judicial Discretion as Affecting Validity" 37 Cohum, L. Reu 1005, 1006 (1937). See also "Constitutiona] Law-Due Process and the Frazier-Lenke Acts," stipia note 30, at II35-36 " "perhaps the most significant conclusions to be drawn about the recent decisions of the Supreme Court in the Radford and Wright cases and the history of the two acts are. . that hastily drafted, more or less ill-considered legislation (as to mearls) will not survive the lest of due process, while carefully worked ott and planned statutes on the saime subject and accomplishing substantially the same chjects will"'.

48 Stat. 195,200 (1933).

${ }^{4}$ Panama Refining Co. H. Ryon, 293 U.S. 388, 405$12(1935)$.

293 U.S. at 410 . The response to this embarrassment was the establishment of the Federal Regisler, in which such orders would thenceforth be officially published. Schlesinger, The Age of Ronsevelt: The Politics of Upheaval, 254-55 (1960)

Harold 5. Tekes, The Secret Diary of Harold L. Ickes, $247(1953)$.

293 U.S. at 430

at. at 421-30. "The Constitution has never been regarded as denying to the Congress the necessary resources of flexibility and practicality, which will enable it to perform its function in laying down policies and establishing standards, while leaving to selected instrumentalties the making of subordinate rules within prescribed limits and the determination of facts to which the policy as declared by the legislature is to apply. Without capacity to give authorizations of that sort we should have the anomaly of a legistative power which in many citcumstances alling for its exerion 
would be but a futility. But the constant recognition of the necessity and validity of such provisions, and the wide range of adminisisalive authority which has been developed by means of them, cannol be allowed to obscure the linilations of the authority to delegate, if our constitutional system is to be maintained." $/ d$. at 421.

"There is no fequirement, no definition of circumstances and conditions in which the transportation is to be allowed or prohibited " $/ d$. al 430 .

1d. at 415 . Referring 10 Section t of the $\mathrm{Acl}$, which sel forth the Acl's policy in general terms. Hughes wrote, "This general outline of policy contains nothing as to the eifcumstances or conditions in which transportation of petroleum or petroleum products should be prohibited, - nothung as to the policy of probubiling, or not prohibiting, the transportalion of production exceeding what the States allow. The general policy declared is 'to remove obstructions to the free how of interstale and foreign commcrce." As to production, the section lays down no policy of limitauon." $/ d$. at 417-18. "The Congress did not undertake to say thal the transportation of 'hot oil" was injurious. The Congress did nol say that transporration of that ofl was "unfair comperition." The Congress did not declare in what circumstances that transportation should be Forbidden, or require the Presicient to make any determination of any facts or circumsiances. Among the numerous and diverse objectives broadly stated, the President was not required to choose. The President was not required to ascertain and proclaim the conditions prevailing in the industry which made the prohibition necessary. The Congress len the matter to the President without standard or zule, to be deall with as he pleased. The effort by ingenious and diligent construction to supply a criterion still permits such a breadth of authorized action as essentially 10 commit to the President the functions of a legislature rather than those of an executtve or administrative officer executing a declared legislative policy. We fitit nothing in section 1 which limils or controls the atsthority confetred by section 9(c).* /d. al 418-19. Nor could any of the Act's other sections the deemed 10 prescribe any limitation of the gran of atuthority in section $9(\mathfrak{c})$." $/ d$, al $419-20$

"If section 9(c) were held valid, II would be idle to pretend that anything would be left of limitations upon the power of the Congress Io delegate its law-making function. The reasoning of the many decisions we have reviewed would be made vacuous and their distinctions nugatory. Instead of performing its law-making furction, the Congress could at will and as to such subjects as il chose transler that function to the President of other offucer or to an administrative body. The question is not of the intrinsic importance of the particular statute before us, but of the constitutional processes of legislation which are an essential part of our system of government." /d. at 430. See Roy G. Tulane, "Constitutional Law-The Oil Control Provisions of the N.I.R.A." 10 Hisc, L Rev! 301, 304-05 (1935). "Id. 81 426 .

Id. al 430. (quoting Hampron \& Co. United Stutes, 276 U.S. 394, 409-1I (1928)\}, The opinton went on to jdentify "anolhei objection to the ralidity of the prohibilion land down by the Execulive Order under section $9(\mathrm{c})$. The Executive Order contains no finding, no statement of the grounds of the President's aclion in enacling the prohibition. Both section 9(c) and the Execulive Order are in notable contrasl with historic practice, . by which declarations of policy are made by the Congress and delegations are within the framework of that policy and have relation lo facts and conditions to be found and stated by the President in the appropriate exercise of delegated authority. If it could be said that from the four corners of the statute any possible interence could be drawn of particular circumstances or conditions which were to goven the exercise of the aulhority conferred, the President could not and validly withoul having regard to those circumstances and conditions. And findines by him as to the existence of the required basis of his action would be necessary on sustain that action, for otherwise the case would still be one of an unfelcered discretion as the qualification of authority would be ineffectual. . . To hold that [the President] is free 10 select as he chooses from the many and various objects generally destribed in the first seclion, and then to act without making any finding with respect to any objecl that he does select, and the circumstances property related to that object, would be in effect to make the conditions inoperative and to invest him with an uncontrolled legislative power." 293 U.S. At 431-32. lnded, such findings were mandated by the requirements of the Fifth Amendmenl: "if the vilizen is to be punished for the crime of violalling a legislative order of an execulive officer, or of a hoard or commission, due process of law requires that it shall appear that the order is within the authority of the officer, board of commission, and, if thal authority depends on delerminations of fact, those determinations must be shown." Id. at 432 .

"Comment, "Constitutional Law-Delegation of Legislative Powers- National Industrial Recovery Act." 8 So. Cal. L. Rew 226, 229 (1935). See also Chatles K. Butdick, "Constitutional Aspects of the New Deal in the United States," 13 Can. B. Rew 699. 710 (1935) (the particulat situation. . can be met easily by a more definite congressional declatation of policy and purpose to cuntrol the President's fulure exercise of discretion"); Carl H. Baesler, "A Suggested Classification of the Decisions on Delegation of Legislative Power," I5 B. U. L. Rev. 507, 529 (1935) ("If a standard-a reasonable one-had been provided il is fair to assume that a contrary result would have been reached"').

${ }^{4}$ "Section $9(\mathrm{c})$ of the National Industrial Aci could have been reenacted by the use of the same language that was in the original act with probabiy 10 10 20 words addikional to bring it within the rule laid down by the Supreme Court." 79 Cong. Rec. $2135-36,74^{\text {in }}$ Cong " "Sess- (Febnuary 18, 1935).

"Joseph H. Muelher, "Constilutional Law-Delegation of Legislative Power-National Industrial Recovery Acl," 23 IU. B. J. 269,270 (1935), (ciling Theodore W. Cousens, "The Delegation of Federal Legislative Power to Executive Officials," 33 Mich. L, Rev 512. 544 (1935) 1"those who look to the Supreme Court for protection against extensive delegations to the 
Executive should not take too much onfidence from this decision. No substantial barric to delegation is raised by the Panama Refining Co. case. A standard must be sat, but previous cases leach how wague such a suandard may be. .

The Court has indeed sel a limit, but it is formal rather than substontial and the slightest care in bill drafting will avoid jnfinging il. All in all, we may conclude that the case changes molhing and that is importance can very easidy be exaggeraled"y). See also Note. "Delegalion of Power by Congress," 48 Harv. L. Rev. 798,806 (1935) ("lhe new requirement [of a finding] may accomplish no more than to add a fonnality to the issuance of an executive order").

Franklin D. Ronsevelt, Remarks at Press Conference (Jan. 9, 1935) quoted in Schlesinget, supro nole 45, at 255."[T]he mistakes involved seemed exsily remediable, and the adnimistration look the adverst decision philosophically." Id. William Swindler agreed: "careless draftsmanship. . proved to be the crux of the maner, and the optimists emong the Presidential advișers professed to see no serious theat to their general statutory program emerging. . . In the "hor oil' decision. . the oplimists took heart from the fact that the point was a procedural one which could be remedied by statute. .. "Swindler. Court and Constitution In the 'Twentieth Century: The New Legality, 1932-1968 33 (1970).

Jckes, supura nole 46, al 273.

S. $1190,74^{\text {th }}$ Cong. 1' $1^{\text {sh }}$ Sess. (1935), introduced at 79

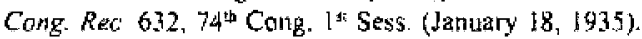
The Committee on Mines and Mining reported the bill back raworably the same day. $1 d$. at 649 . The rwo-andone-hat page report, which consisted principally of quotations from the Pandma Ra/hnimg opinion, claracterized the new bill as "a substantial bul somewhat elaborated resnactment of section $9(\mathrm{c})$ of the $\mathrm{Na}$. lional Industrial Recovery Acs. . . " See S. Rep. No. 14, 74 Cong. I" Sess. I (1935). The reporl of the House Comniltee on lnterstare and Foreign Commerce. issued on Valentine's Day, explained what had been wrong with section $9(c)$ and how the new bilf repaired the problem

Seclion $9(\mathrm{c})$ did nor declare anylhing to be illegal until the President should so ditclare. In making such declaralion. the Congress, in the opinom of the Supreme Court did not require the President to adhere to any legislative policy, or to follow any slandard laid down by $i_{1}$ or in fact to be guided by any rule. No patticular cifeumislancess, or cond jtions were set forth as a perquisite [sic] to the President's declaration. The Supreme Court construed this action by Coneress to be an invalid delegation of authority.

I $5, I 190$, as amended, Congress declares in no uncertain lerms that such shipments, or transportation, in interstale commere as dafined therein, is prohibited, and violations of such Federal law is [sic] purishable in the manner prescribed lmmediately upon the passage of this act, therefore, shipments in interstate commerce of petroleum and petroleum products, as defined, become a violation of the law and there is no delega- tion of authority to the President to determine anylhing before such law would become operalive.

H. Rep. No. 148, 74th Cong. 1" Sess, al 1-4 (1935); see Commenl, "Interstate Regulation of "Hot Oill," 23 Geo L. J. 487. 492-94 (1935).

In the Hot Oil Cases, Connally rematked on the foor, "The Supreme Cour held and I think prop" erly so. that the Congress did not possess the power to delegate authority to the President to put the prohibition in effect or not in effect os he might determine. . . The Court indicated, in harmony with other decisions heretofore made, that had the Congress set up a standard or a messure by which the President could determine when and when not the shipment of oil should be protibited the act would probably have been held valid." 79 Cong Rec: 693-94, $74^{\text {H }}$ Cong. $1^{\mathrm{H}}$ Sess. 1.January 21, 1935).

As Connally explained it. "In the first section of the blll there is a declaration of the poliey of the Congress. One of the suggestions in the decision of the Supreme Cout was that Congress had nol declared any particu. Iar policy but had merely delegated its authority to the President. The dectaration of policy here is that in order to remove the burden of minterence with interstate commerce by contraband oil, and in order 10 cooperate with the various slates to that end, the Con gress prohitits the interstate shipmenl of oil and ol products when the particular oil has been produced or refined or handled in viblation of some State law or some valid regulation or order of the State commission. ... Section 2 then absolutely prohibits the shipment in interstate or foreign commerce of oil produced in violation of state law or regulations." $I d$.

"Id. See also remarks of Sen. Comnally, id at 753; remarks of Rep. Dies, id at 2124 , renarks of Rep. Wolverton, id. al 2135-36; remarks of Rep. Dempsey. id. al 2150 . Senators King and Borat raised delegation objections to Section 3 of the bili, which athorized the President or his duly designated agent or agency to make such rutes and regulations as might be found necessary or appropriate to eflectuale the purposes of the act. $J d$. at 762 . Connally responded that this sort of defegation had been repeatedly upleid by the Court, ciling as an example United States is orimoud, 220 U.S. 506, in which the Secretary of Agriculture had been given very broad power to make rules and regulalions with respect to the foresl reserve. 79 Cang. Rec. 763, 74th Cong, 14 Sess. (January 22, 1935). Borah responded: "Yes; I know the Supreme Court has upheld in some instances these regulutions, under certain circumstances. but $I$ invite the Senator's atumion to the fact that when these cases were first presented to the Supreme Court of the Liniled States, nules and regulations, the violation of which eonsiltuted a crime, were heid invalid. The Court modified its position upon the question. I venture to say that if we continue to make these rules and regutations by the thousands and thousands, the violations of which conslutute a crime, the Supreme Cour will go back some of these days to the very sound and safe rule which it announced in the beginning when it firsl dealt with the question. There may come a time, as in the decision in the ail case, 
when the Court will conclude a danger point has been reached." $l d$. al 763-64. Connally repled, saying, "tn a large measure I agree with the Senator in the idea that it is rather drastic io authorize any department in make rules and regulations punistrable by fine or imprisonment, but the principle has been established and followed over and over again. linder this particular measure, of course, the Department cannot prescribe any rule beyond the scope of the direct authority which the Congress grants." Id. at 764. See also the colloquy between Rep. Disney and Rep. Cole of Marland, id at 2146.

ld. at $764 ;$ id. at 2150 . Hughes' specific advice on how to frame a constitutional delegation was not wasted. Section 4 of the Connally Act provided that "Whenever the President finds that the amount of peraleum and petroleum products moving in interstote commerce is so limited as 10 be the cause, in whole or in park, of a lack of parity between supply. . and consumptive demand. . . resulting in an undue burden on or restriction of interstate commerce in petroleum or petroleurm products, he stall by prochamation declare sucli finding, and thereupon the pror visions of section 3 [prohibiting interstate shipment of "hot oil"] shall be inoperative until such time as the President shall find and by proclamation declare that the conditions which gave rise to the suspension of the operation of the provisions of such section no longer exist." c. 18, section 4, 49 Stal, 30 (1935). As Representative Charles Wolverkn observed, "The House committee. . has placed in this bill something of a safely valve, in that the President is authorized and empowered in suspend the act if it should appear that the limitation or control of production of crude oil was detrimental to the national interesi. If that prowision had nol been placed in this bill, it would have lef the entire malter to the judgment of an oil producing state as to what quantity of crude oil should go inio interstate comnerce. . . [The bill as amended] has not left it entirely to the State to detemine, without regard to the rights of the consuming public, how much oil shall go into interstate commerce. Provision has been made that whenever the President finds there is such a limitation of produclion as might be hamful to the consuming public he can aet to suspend the prowisions of this bill. Thus there is a safecy valve provided in this bill. ..., "id. at 2136 . The House report explained the masnes in which the proviso had circumscribed the Presidenl"s discrelion an compliance with the Panama Refining decjsion- "The commitlees inserted the proviso found in the bill, which does not arbiirarily delegate to the President the power to declare the law to be moperative in his sole discreion, but only when he finds that the eircumstances exist which are set forth in the stanute. Congress says to the President in effect int the langrage of the amendment-

You are pemitted to declare the existence of the facts by which this law shall be inoperative whenever you find that the supply of petroleurn and the products thereof, moving in interstate commerce, is so limited as to cause in whole or in part a lack of parity between supply, including imports, and demand, inciuding exports, resulting in an undue bur- den on, or restriction of, interstate commerce in pelroleum and the products therent.

Under this language the Presideri, we assume, will require a factual basis for his finding, that factual ninding being addressed to what limitation there is upon the supply moving in interstate commerce and whether there is a lack of parity between such supply and demand. This is a definite requirement, a stakement of circumstances and the imposition of conditions, all of which must be determined before the President call act. This power in the President presupposes a definite finding and a statement of the facts for the President's action before any such action is taken." H. Rep. No.

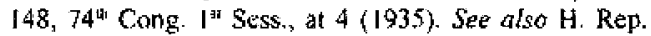
$2155,74^{\text {th }}$ Cong. $3^{31}$ Sess., at 5 (1935). There are no reported cases chatlenging the validicy of section 4

Comment, "Constivutional Law Delegation of Legistative Autlority," I Mo. L. Rew 68, 70 (1936). See also Isador Loeb, "Constitutional Interpretation in a Transitional Period," 21 St. Lours L. Rev 95,102 (1936).

"Note, "Constitutional Law-Delegation of Legislalive Powers- "Hot Oil-NIRA," $3 G$ W L. Rew 391, $392-93$ (1935).

"Note, "Delegation of Legislative Powers in the Execulive - the NIRA Oil Case," 2 U. Chi. L. Rew 632, 636 (1935). For olher optinistic assessments of the Act's chances before the Couri, see Note, "Constitulional Law-Delegalion of Powers-Validity of Act of Congress Confetring Discretionary Authority Lpon the President," [2 N.YU. L. Q. Rev 520,522 (1935); Genrge K. Ray \& Harvey Wienke, "Hol Oil on lincharted Seas of Delegated Powers," 29 III L. Rev 1021 , 1034-35 (1935); Comment, "Interstate Regulation of "Hol Oil," 23 Geo L. J. 487, 494 (1935).

See Genecov v. Federal Fetroleum Board, 146 F. $2 \mathrm{~d}$ 596 (Sth Cir., 1944); The Presidem of the United Slates v. Skeen, 118 F. 2d 58 (5ih Cir., 194 [); Hurley $v$ Federal Tender Board No. 1, 108 F. 2d 574 (5th Cir., 1939); Grismold v. The President of the United Stares, 82 F. 2d 922 (5ih Cir., 1936); President of the United Siates v. Artex Refineries Sales Corp., 11 F. Supp. 189 (S.D. Tex., 1935).

United Siates v. Powers, 307 U.S. 214 (1939).

Ch. 824, 49 Stat. 991, 995-100 I, section 4, part II (1925) (repealed 1937, as noted in 15 L.S.C. sections $801-827)$.

is. al 100$]-02$, section 4 , part Ill.

See Barry Cushman, Rethinking the New Deal Court: The Structure of a Constitulional Revolution [59-6] (1998).

298 U.S. $238(1936)$

id. at $312-16$.

$7 d$ at $317-24$ (separate opinion of Hughes, C.J.).

If at 324 (Cardozo, J., dissenting), Cardozo main tained that "the suits are premature in so far as they seek a judicial declaration as to the validity or invalidity of the regulations in respect of labor, " and accord ingly did not consider the validity of those provisions. Ld.

id at 336 .

See Comment, "Constitutional Law-The Guffey Coal Act Decision and the Future for Fedecal Price 
Regulation," 160re. L. Rew. 67, 79 (1936) (noting that "by stabilizing [through price regulation] an industry in desperate economic plight and placing it in a position where it caut affotc to pay decenl wages to labor, Congtess may avert much of the damage to the public welfare from labor difficulties, and muth of the need for dinet regulation of wages, houts, and other labor conditions, which cannol be constitutionaliy imposed, in the opinion of the Supreme Cour at the present iime"). See also Comment, "The BiAnminous Coal Act of 1937, , 25 Geo. L. J. 986,989 (1937); H1 Rep. No, 294, 75" Cong. I" Sess., at 2(1937) ("It is the opinion of the commiltee that the stabitization of prices which the bill secks to effect and the resulting guaranted to operators of a tair price for their coll will go a long way toward stabilization of labof conditions it the industry and toward the guarante to the miners of satisfaclory working conditions and a living wage").

See "Constitutional Law-The Guffey Coal Act Decision," supra note 76, at 67. 71-79; Note, "The Final Phase of the Schechter Episode: Carter v Carter Cool Co.," 5 booklyn L. Rev. 454, 469-70 (1936), Comment, "The Bituminous Coal Conservation Act ar 1937." supra nole 76, at 992-93.

50 Stat. 72 (1937).

See S. Rep. No. 252,75'th Cong. $1^{\neq 1}$ Sess. at 4-5 (1937); H. Rep. No. 294, 75' Cong. I" Sess., at 11.14 (1937); rematks of Rep. Dirksen, 81 Cong. Rec. 2120 . 7Et Cong. 1" Sess. (1937); remarks of Sen. Guffey. id. 5t 2950-52; remarks of Sen. Borah, id. at 2956; remarks of Sen. Neely. id; temarks of Rep. Vinson, id. at 2033-34, 2036-38; remarks of Rep. Jenkins, id. at $2041-42$.

See, e.g., Nebbia y, New Yark, 29 ! U.S. 502, 599 (1934) (McReynolds. J., dissenting).

291 U.S. S02 (1934); Il. Rep. No. 294, $1175^{\text {th }}$ Cong. $1^{\text {in }}$ Sess. (1937): remarks of Rep. Guffey, 81 Cong. Rer. 2953, 75th Cong. 1: Sess. (1937); remarks of Rep. Vinson, id at 2030, 2034, 2038-39: remarks of Rep. Jenkins, id. at 2042.

Id. at 2039. See olso Comment, "Constitulional Law- Biruminous Coal Conservalion Act of $1935-$ Congressional Power Under the Commerce Clause to Regulate Labor Conditions in Local Industry and Fix the Price of Sales in Interstate Commerce," 34 Mich. L. Rev. I167, 1178-79 (1936) (suggesting that Nebbio provided authority for federal regulation of the price of coal sold in interstate commerce); "Constitutionat Law-The Guffey Coal Act Decision," stipra nole 76. at $76-79$,

See, e.g. remarks of Rep. Jenkins, 81 Cong. Rec. 2041, 75 Cong. 1" Sess. (March 9, 1937).

Ralph Baker. The National Bituminous Coas Commission 66 (1941). See renarks of Rep- Jenkins,

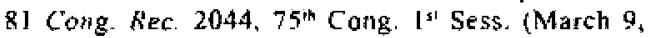
1937); remarks of Rep. Casey, id. at 2047 .

Sé Custiman, supria note 70, at 195.

81 Cong Rer. 2952, $75^{\text {th }}$ Cong 1" Sess. (1937). Id at 2032

Sunshine Anthracite Coal v Adkins, 110 L'S. 38I, 395-97 (1940).

Act of June 27, 1934, c. 868,48 Stat, 1283.

"The fact that the compulsory scheme is novel is. of course, no evidence of unconstitutionality. Even should we consider the Act unwise and prejudicial to both public and private interest. if it be fairly within delegated power otw obtigation is to sustain it. On the other hand, lhough we should think the measuje enbodies a valuahle social plan and be in eltite sympathy with its purpose and intended resulis, if the provisions go beyond the boundaries of consitutional power wa Trust sa declare." 295 U.S. at 146.

Id. al $348-57$.

lal at 362 .

"Classes of persons beld to be improperly brought wilhin the rasge of the Act could be eliminated. Criticisms of the basis of payments. of the conditions prescribed for the raceipt of benefits, and of the requirements of contributions, contd be mat. Fven in place of a unitary retirement system anothet sorl of plan could be worked oul." Hal al 375 .

7.4. 7 . at 375

75 ld al 174.75

Se Ser, e.g. Comment. "Constilutional Law-Railroad Retirement Act," 4 Fordham L. Rev. 498, 499, 501 ( 1935 ): Comment, "Constimlional Law -..Due Process-Interstate Conmerce-Power of Congress 10 Provide for Compulsary Retirement and Pension System for Carriers," $20 \mathrm{Mm}$ L. Rev 49, 55.56 (1935): Comment, "The Railroad Retirement Acts", 10 St. John's L Rev 53, 58-59 (1935); Comment, "Consttutional Low-Railroad Retirement Acts" 25 Geo. L. J. 161, 173 (1936); Comment, "Conslitutional LawThe Railroad Retirement Act--Interstate Commerce-Due Process," 33 Mich. L. Rev 1214, 1220 (1935); Bnce $R$. Trimble "[he Judicial Treatment of the New Deal," Kan. City L. Rev 104, 107 (1936). See also "Radio Address of Hon. John A. Martin. of Colorado, on March 6, 1937," reprinted in 81 Cong. Rec. Appendix 435-37, 75 Cong. 1" Sess. (1937); Samuel Hendet. Charles Evans Hughes aod the Supreme Court 231-32 (1951): William E. Letuhtenburg, The Supreme Court Reborn 46-47 (1995)

Ralph F. Fuchs, "Iudicial Method and the Constirutionality of the N.J.R.A." 20 Si. Lowis L. Rev 199. 209 n.34 (1935) (emphasis mine). See also Cornient. "Constilutional Law--Uncoustitutionality of the Railroad Retirement Act--Limitation on Power of Congress Over the Insirumentalities of Interslate Commerce," 35 Colum. L. Rev 932, 933 (1935) (suggesting that the powers to tax and spend were "broader in scope than the commerce power, and night therefore permit congressional legislation creating a pension system for rallway employees].

${ }^{93}$ tot.

"See Note, "Constitutional Law-Railroad Retiremenl Acls," supra note 96, a1 165-66, 170

waked by Senator Duffy whether the revised Rat road Retirement Act met the objections raised by the Court in Alon, Senator Wagner responded that Alion "was based upon the ground that we had no authority. under the power to regulate interstate commerce, to retire old rilway cmpinyees. . Under this bill. . , we are proceeding on an entirely different theory, mainely. the power of Congress to impose taxes." 79 Cung. Rec. $13646,74^{\text {th }}$ Cong. I" Sess. (August 19,1935). In the Howse, Rep. Monaghan pointed out that Robers' Atom opinion had held "that the power "to regulate 
commerce' did not earry with it the power to provide pensions. He did not say we could not pay an annuity out of the Treasury of the Uniled States. [Thal] is the theory of this bill." /d at 1367 I.

49 Sial. $967(1955)$

49 Stal. 974 (1935)

:al II all began when Senator Hastings asked why dye provisions imposing the laxes and the provisions at thorizing the appropriations were not all in one bill, as they were in the Social Security Act. Senator Wagner responded eryptically that it was "a matter of procedure." Senator Robirson came to Wagner's rescue, explatning that "Nomatly the Committee on Interstate Conmerce has jurisatiction of railtoad pension legisla lion. Always the Firance Conmiltee has jurisdiction of tax legislation. In the ase of the social-securily bill, it was my personal thought that it would be better to separate the legislation. to have the administrative and other provisions in one measure, and the tax provision in a separate measure: but that course was not followed. In the case of the railroad pensions, that course to teing followed, and I helieve it is the best

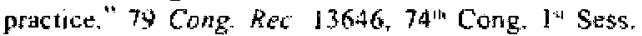
(1935).

Hastings was nol satisfied. "May 1 inquire," he inquired, "whether there is any objection to widing a new title to this hill, including the lax, instead of passinc a separafe bill?" "Yes; there is a valid objection," Robinson responded. "IT]he Stnate has no power to originate a revenue ineasure, and the body at the other end of the Capitol probably would take the view that we wark onginating a reventue measure if we put into this bilt a provision for the tax to which the Senalor is referring." "May I inquire. . why it was lijat the House mate these two separate bitis". Hastings persisted. "There was no reason why the Holise could not add the taxing tearure to the bill. Why did they nol make it in one b!ll?" "That is the business of the House." was Wagner's curt if somewlital juverile responise. Id. at 13647 .

Kobmons's tactic was to return to the thenve of sommitee jurisdiction: "Mr. Presidenu," he explained. "it may or may not have been due to my owin suggesfidi. I felt then and still feel that the conmutace which has jurisdiction of the legistation to provide for pensions, to work out the administrative features, is a different commote from that which has the tax-raising authority, and I think the course that has bect pursued is the better course. Our commitlee formuIaled the legislation-a committer which is famitiar with the subject matter of this bill. The laxing contmitee, the Wys and Means Commitere, is composed of men of eminence and of ability: nevertheless they have not ande the snudies and do not possess the knowledge of this particular subjecl which is essential to proper forntulation of the lagislation. So I think the course which the House has pursued is a good one. I an perfuctly willing, if the Stentor thinks otherwise, to have him get them to teverse their action if he can do so." $/ d$.

Wagner had by lhis point caught on to Robitison's strategy, and now thined in: "Mr. President, let The say, un fine with the suggestion of the Senator from Arkansas, that like the Interstate Commerce Com- mittee of the Senate, the Interstate Comnerce Com: mitce of the House last year devoted severat months to the sludy of this whole subject. Hearings covered a period of at leasi one month. Experts upan this question, those representing the railroad point of view and those representing the employees ${ }^{*}$ pont of view, ware beatd. In view of this long staty it would seem th ludi. erous procedure to send the measure deliberately to another tommiltee which wauld have to begin the bearings all over again and study the question de novo." Id.

Robinsont then lasd hare the issue Hastugs had been snifing around. "I assure the Senator from Delaware that the course which has been pursued does not involve any legerdetrain, if that is what the Senatge is Inlimating." "I an glad the Serkator ussures me of that," Haslings replied, "becduse I an very suspicious of it . . In Ithis cuse a very clever thing has been done, by design or olherwise, which is to separate the granting of a pension from the levying of the tex. . . I say that that in my judgment makes very mucl more certan the constitulionality of the lwo acts, but I say in doing it Senators are violating the spirit of the Constitution, and what 1 am trying to find out is whether or not it has then done deliherately and for the purpose of making more certan the constitutionality of these two bills." $/ d$.

Wagner stuck with Robinson's game plan, insisting, "I hoow of no such detbefate design. I think a very clear and porsuasive explanation was made as to why the two bills went lo lhe separate commiltees." But Robinson, seeing a forensic opporturity where Wagner did not, had shifted ground.

"It the Sentor from Detaware is in synpathy with raihroad pension legislation, if he befieves that $\mathrm{il}$ ought to be enasted, he certainly cannol objecl to any course the Congress might decide to lake which would lend to sustain the Jegislation after it had been passed," he contended. "There is nothing wrong, there is nothing inmoral, and there is nothing treachetous in sepaFating the two subjecs. They ought to be separated for the reasons which I gave a few moments ago." Here he rejoined Wagner, "One committee st familiar with the subject matter of one phase of the legustation; another conmitte is familar with the subject matter of the tax legistatuon. Yet the Senator from Delawate is suspicious that there is something wrong with the policy of passang two bills orie as a tax bill. We seldom put tax legislation in the bills we enact for the expentiture of money. It was the consistent course which was purstued." Id at $13647-48$.

Here Senator Borah drove home Robinson's defense of separating the bills as a constitutional strategy. "I understand the question which is raised trere is to what the effect constitutionally will be by reason of providing the lwo measures," he observed, "Suppose., Ihe legiglation is brought within the Constitution by reason of that fact, is it not our duty to do that wery thing?" At this poinl Wagner again caught up lo his collengues, half admitting what he had denied a moment earliet. "That rs what the Senaror from Arkansas suggested." he agreed, "and I tried to suggest that if we are friends of this messure and anxious to provide a pension for the ennployes, if the Senator is right, that is the very course which we ought to putsue." $I d$. at 13648 
There followed a colloquy among Serators Wagner. Fletcher, and Barkley, in which al was made clear that the pensions were to be paid oul of the Treasury "out of any funds not otherwise appropriated," and that while the tax "has been figured oul so as la conform to the actuarial requirements" of the pension legisiaton, there was a "thaoretical relatonstip berween the two" bills, "but not a d. rect connection." Id. 13648-49. For a similar disclission in the House, nete id at 13670-71 (remarks of Mr. Hollister). This prompted Senator Tydings to launch the second of fersive against the proponents' constitulional strategy. Throughout the discussion thal followed, Tydings never once let on that his suggestion, if adopted, might compromise the constitutional strategy that lay behind the separalion of the bills. Nevertheless, it clearly would have tended to do so.

Tydings' suggestion was to earmatk the tax and pay its proceeds into a separate fund tather than nixing them in with the general reventue. "I should much ralker have this fund segregated and the retirement benefits paid out of such fund than have the Treasury of the United States, without any limitation witatsoever, become the source from which these payments are to be made," said Tydings. "I believe it is extremely bad policy to have the Federal Govithment made the bank to pay pensions of this character. ..."/d. at 13649 .

Wagner sought to fend thim off by voucting for the plan"s actuarial integrily. "The calculations ate definitely made; they are predictabie as to the almount which witl be required in order to secure a solvent fund for the payment of these pensions; and a sufficient tax is imposed to secure that fund. So whether it be segregated or put into the general fund of the Treasury is really a very minor matler." $/ d$.

if il was sllch a minor matter. Tydings replicd, "l take it the Senator would have no particular objection to segregating these funds under the Railroad Relirement Board?" Wagner hedged, professing solicitude for emplayees of lie Treasury Department: "I should want to consult the Treasury authorities. I think perhaps such segregation would impose upon the Treasiry Department unnecessary bookkeeping and unnecessury work. II is a matter that 1 do not regard os very important, so long as the calculations are definitely made, and that can be done." Tydings then expressed this wish that Wagner "at the very first opportunity. . consull the Treasury aboul the sdvisability of having these moneys segregaled into a separate fund, "to which Wagter responded, "Very well," "I am certain," Tydings persisted, "if the bill were now so worced that it would attract support which otherwise might not be present. I think some Senators feel that a matter that is extraneous Io the Govemment such as these funds, only being atdministered by the Govennent, ought not to be confised witl the general revenues of the Government." $/ d$.

Here Wagner became conciliatory. "I may say that the Senator raises a question really worth while, he conceded. "Under this bill a comtnission is to be appointed to inake an inwestigation of alh the tnatters that relate to this whole subject. . . The conmission tnay, among other things, study the very question which the Senator has raised. Furthermore, the commission is to repert to the Congress on January I next. which will be 3 months prior to the effective date of this particular ack: so that ample time will be afforded so study that very question." I $d$.

Nol quile satisfied, Tydings replied: "Even so, if I may so ask the Senator. I request tha! he ascertain if the Tretasury would look with favor upon it; and if the Treasury should look with favor upon it and the auther of the bill! shoula do so, I should like to see such a provision incoporaled into the law. If subsequently after the examirtation shall have been made, he should find that the noney should be covered into the general fund for one reason of another. that would be a different thing, I do not like lo start the bill out in that form if it can be avoided." Al this point Wagner asked to be let off the hook. "At lhis lete cate," he replied to Tydings, "I hope the Senator will nol press the suggeslion, because the commission will be in a position to study the question and to report to us before any tax is imposed in accordance with lhe design of this bill." $I d$.

Tydings did not press the suggestion, but Hastings rejoined the colloquy to suggest that segregation of the funds rattrer than payment of the pensions out of the Treasury would be facul to the scheme's constitutionatity. Wagner attempted to cut Hastings short. "There is no need of going into that; I know the Senator's point of view from the standpoint of the law upon this subject; but there is no need of our fussuing it any further. The courts will finally have to speak upon that question." $/ d$, at $13649-50$.

But Haslings had to have the last words, and they dripped with barely conceyled sareasna and disdain. "Mr. President, I think this method of legislating is establishing an exceedingly bad precedent, 1 was delighted to heat the Senator from New York [Mr. WAGNER] suggest that it was not designedly done. I had the dislinct impression that the Social Security Act, as to the constimitionality of which many of us had serious doubt. was divided into separtte titles because the fear was existent that if the fund were segregated, as the Senator fron Maryland [Mr. TYDINGS] suggested be would like to see done, there would be very grave danger of the act being declared to be unconstimional. . When I found in these two bitts that the two proposals are separated entirely, I reached the conclusion that some smat person had probably thought he would be able to circumvent the Constitution in that way 1 was not cerain and 1 am not now ceriait whether the Supreme Court may lake the two acts together in order to delemine whether both or either may be constitutional.

"As an illustration, when we pass the second bill providing for a tax upon railtoads. thete is no doub: that nolhing in that measure will show the purpose for which the tax is levied. The Federal Government may take it, may puy the pensions dut the World War veterans, may use il for relief, may uge it to assist the farmers, thay use it as the Federal Government may use any other part of the generat fund which comes into the Federal Treasury. That is undoubledly true. There is no earmark to the taxation. . . But the query I have in mind is whether or not the Supreme Coun may lowk at the two acts and deternine that the tax was fevied for a purpose.

"I do not raise the objection here for any other reason than to caution the Senate against this kind of legistation which separates a $14 x$ bill from the pumpose of the tax itself. I think unless we can combine the 
two. and safely combine the rwo, we ought not in anact it at all. I ath not in favor of circumventing the spirit of the Constitution in any way, we have developed new and important minds recently. They have new ideas. If seems to me that this is one idea which they might be able to "put over.' [ am glad, in view of that thought, to hear the Senator from New York [Mr. WAGNER/ say it was not done designedly, that it was not for any such purpose as that.

"With that statement in the record I assumc tho Supreme Court, when thcy come to consider one of these ads, will fecl justified in considering bolh of them and resding the record in order to ascertain whether or not we have done a lawtul thing." $t d$, at 13652

In the House, Rep. Merritt echoed Hastings' objections. "Mr. Speaker, 1 do nol propose to make any general spocech or argument against this bi]l, but I think the Members of the House, if they do not appreciale already what it is proposod to do, should have it called to their attention. What we are dotng roday is to reen. acl a part of a bill which has aiready been declared unconstitutional. The way $n$ is proposed to avoid the decision of the Suprome Cour is to divide the bill into two bills, and pass this bill, which gives the people why are affected by it. a generat claim on the Uniled States Treasury: and theth this aftemon to pass ath appropriation bill to cover the supposed expense which will be incurred by this pension bill." $d d$. 13673. Sea also remarks of Rep. Hollister, id. at 13671 .

Alton R. Co. to Railrood Ketimemen Board, $16 \mathrm{~F}$. Supp. 955 (Dist, D.C., 1936).

iais lat as6-57.

10. "The iwo laken together so dovetiil into one another as to create a conplete system, stbslantially the same as that created by the Railroad Rebitement Act of 1934. . . The provisions of the two acts in question are so inlerselaled and interdcpendent that each is a necessary part of one entise scheme. This is not orty appatent from the terns of the acls themselves, but is shown by thetr legishative hislory. It was ctearly the iritention of Congress that the pension system created by the Retirement Act should be supported by the taxes levilod upon the carriers and their cmployees. " $/ 4$. at 956 . "In the case at bar, , the interlocking and irsterdependent provisions of the two acts and their legislative history do shaw an attempi to accomplish under certain of its powcts an end which has been told to be unconsirutiona]." $/ d$. at 957. "[F Jrom what has ben said il necessurily follows that the two acts are inseparable parts of a whole, that Congress would not have enacted one withoul the other, liat the taxes lowicd under the tax act are the contribulions required under the act of 1934 . . . This being true, it ts clear that under the views of the supreme Cour in the Alton case the taxing act transcends thi powers or Congress. The pension system so created is subslantially the: same as that created by the act of 1934, and, apan from its unconstitutionality as a whole, subject to the same objections in certain particulars as those pointed out by the Supreme Court in that case. "Id. at 958 . The cotri identified some of those particulars id. at 959.

The court rejected the claim that the two acts had to be considered cntirely separately becausc "the funds arisjng from the taxing act are not 'car marked,' not kept as a separate fund for the payment of persions provided for in the Retirement Act. .. [T] The purpose of Congress in passing [the Taxing Ack] is clearly as shown ... to provide funds for pensions. . . and not to provide for the expenses of the governmenl." That being so, "it would seem to be immaterial whether the funds raised by the tax act are to be segregated in the Treasury; that would be a mere marter of bookkeeping, and would not affect the right of the taxpayer." Id at 957 .

Several commentalors had predicted this fate for the I935 pension legislation. See, e.g. "Congtitutional LawRailroad Retirement Act, "supra note 96, al 499.501; "Conslitulional Law Due Process-Intersiate CommercePower of Congress 10 Provide for Compulsory Retifement and Pension System for Cartiers," supra note 96. at 5556; "The Railroad Retirement Acts," supro note 96, at 58 59; "Constitutionth Law-Railroad Retirement Acts." supra note 96. a: 173 .

This is reported in $B$ \& $O, R$. Co v Magruder, $77 \mathrm{~F}$. Supp. I56, 156-57 (D. Md. 1948).

As Rep. Lea, Chairman of the House Committe on Interstate and Foreign Commerce explained in introducing the Railroad Relirement Act, "Representstives of the 21 standard ratiwy employees" organizations represcnting substantially all ranlway employses on class I railroads participaled in the negotiations, Rajlway managenent representing $981 / 2$ percent of the total mileage of class 1 raitways of the Unted States parucipated in the negotiations. Class I railtoads, as the membership of the House is aware, embrace tvery railroat whose anntul income is over $\$ 1,000,000$.

"Members of the Faderal Railroad Retirement Board participated with representatives of the management and men in these conferences. Finally an agreement was reached. the substance of which was embodied in a bill broughl belore the Interstate and Forsign Commetec Commiltee of the Housi. As a result of the hearings and futther consideration of that measure by our commilte a number of changes were made which wore approved by these two groups and cmbodted in the bill now presented to the House." 81 Cong. Rec. 6080-81, 75" Cong. $1^{\text {F' Ses. }}$ (June 21, 1937). The Commilice Reports smilarly noled that "The pending bill las received the endorsement of both the labor organizations and the carriers, expressed in horings before the commitlee." H. Rep. No. I07I, $75^{\text {lh }}$ Cong. $1^{\text {ta }}$ Sess., at 2 (1937). See olso S. Rep. No. $818,75^{\text {th }}$ Cong. $1^{*}$ Sess. at $2(1977)$, which adopted the Housc repon as is own.

As Representalive Doughton explained, "The matler was given long and painstaking considerarion, and was thoroughly discussed with the employers, the employecs, and representatives of the Treasury Department. Aftet long and deliberalc consideration the meastre now has unanimous support. It is agreed to by those who will pay the tax, it is acceplable to the Trensury of the United States, and it has the unanimous support of the Comminte on Ways and Means." 81 Cong. Rec. 6302, $75^{\text {th }}$ Cong. $1^{\text {st }}$ Sess (June 24, 1937). "Representatives of the railroad men, represtented by Mr. George Harrison, president of the 21 brotherhoods, came before our committee," noted Representative Jenkins, "and indicated that they favored this lagislalion. The railrod executives, represented by Mr. Fletcher, a capable and able representative, siated that 
they, too, were in favor of this legistation." Id. at 6.303 . Representative Wolverton reported that the District Court's injunction "prompted the President to suggest to veprescnLatives of railroad labor organizations and railroad managenent that an cfort be nade ro work out between them a retirement plan which would be mutuslly satisfactory.

"Ir accordance with the suggestion of the Presiden. a committee was appointed by the Association of American Railroads to confer with a committee appointed by the Railway Labor Execulives Association, representing the employes. As a result of the conferences held by these two representative groups the plan of retirement was agreed upon and is embotied in amendments to the existing law. The bill now before the House. represents that plan as agreed upon by the carriers and their employees and approved by the Committe on Interstate and Foreign Commerce after care ful study and extensive hearings. The eraactment of this bill in irs present form has been agreed upon by all the interested parties." The bill "represents absolute and complate unam!mity of thought and desire betweer management and men. There is no feature of this bill that prcsuts any controversy or disayteement as be. fween these two parties. Every provision has the suppor of both without any rcsisration on the part of either. It represents a unifted effort to produce legistation that wilk be salisfactory and mutually beneficial, and comes be fore the House with the united stpport of raifoud management and all the standard brotherhoods " $/ d$. at $6084-85$. Sec also is. al 6302 (remarks of Rep. Snell); id al 6085-86 (remarks of Rep. Martic of Colorado); id. at 6087 (remarks of Rep. Mapes): id at 6087-88 (remarks of Pep. Cole of Maryland); LA a 6089 (remarks of Rep. Mead); id at 609 ? (remarks of Rep. Raybum)i id. at 6222 (remarks of Sen. Wagnet)' id. at 6224 (remarks of Sen. Wheter); wh a1 6227 (remarks of Sen. Barkley).

Sponsors also explained the constitutionat theory of the plar. and the reasons why it was being endected as two bills rather ilyan one. Representative Jenkins explained that "I! was thought advisable to divide these bills and permit the bill providing the amount the railroads should pay and the ntather of paynent and all incidents thereto to be considered by the Weys and Meani Comnictes, which of right should consider it And il was aiso thought advisable that arother bill should be introduced providing wha should be eritled to draw this persion and how much each class should draw and also to provide wist age men should be required or be eligible to draw the pengion." Id. at 609 t.

In the Senate, Senator Davis explaned trat "The measure now before us is not predicated upon the power to regulate commetce, but upon wo separale and distuct powers vested by the Constitution in Congress, neither of which was involved in the case holding the Retireme' act of 934 to be void

"The measure now before us is predicaled upon lite right of Congress to appropriate money. Section 12 authorizes an appropriation for the purposes of the bill out of the Treasuly of the United States. This appropsiation is not payable oul af any particular fund. nor out of any money earmarked for that purpose." fd, at 6227 . See also id at 6303 (remarks of Rep. [enkins).

In the House there was a mild reprise of the collogly Senalors Wagner, Robinton, Haslings, and Tydings had held in the Senate two years earlier. Representa- tive Fish asked: "Is any of this money earnarked for this purpose when it goes into the Treasury?"

Representatwe Fred Vinson repliod that it was not. "This is a taxing bill that produces revenue collected by the Bureau of Internal Revenue. Thte revenues go directly into the Federal Tressury, the general fund of the Trzasury." Fish responded, "I siniply want to ask the gentleman if there is any season why this money should not be earmarked for this specific purpose."

Vinson replicd that "So far as this act is concerned, the act covers the money into the Treasury of the United States. Congress has the power to appropriate llis money jusl as they approprate all other money that goes into the general fund of the Treasury."

This was uniesponsive, and Fish iold Vinson so. "But the genteman has nol answered my question Why should in not be earmarked?"

The future Clmef Justice answered: "Because, from the beginning of our Gowermment, until now, as I am informed. the policy of the Treasury thas rever been to eamark money coming inlo the general fund of the Treasury . " Bun "What abour the Congress?" tetorted Fish. "Cannol Congress do thar?" Hete Vinson was finally forthcoming: "1 recall one inslanee when the Congress attempted to collect taxes for a specia! pumose, which may be characterized as earmarkingit was the Agriculutral Adjusment Acr. The processing taxes were held by the Supreme Cout ia be an exaction which, under the act, did nor go into the general fund of the Treasury, bot were used for a specific purpose which the Supreme Courn held to be beyond congressional power. I an cettain that my friend from New rork will recognize that a recurrenes of that sort of thing is not desirable. So I tepeat that this aut is what it says it is lhe Carriars Taxing Act of 1937-a revenue bill in wheh the revenue will be cotlected by lite Bureau of Internal Revenue, as other caxes ate collected, and they will bocome part and parcel of the gemeral fand af the Treasury of the United Srates." H. al 6307-4

If Mr, Fist though that such a recurence would rave buen desirable, he did nol say sa. Debale corttududed and the bill was passed without a record vole. 1d. at 6304, The bill passed the Sornate without debate and without a record vote. $I d$, at 6345 .

Rentarks of Sen. Davis, id at 6227. This cohoed the tncomiums of the Comnittee Reports, which stated: "we wish to commend both the carriers and the employecs upon the great ability they have shown to adjus matuers of this sorl through normal process of collective bargaining. The agreemint as to this measure constitutes a landmark in the laistory of industrial relations in chis country ${ }^{\text {"H }}$ H. Rep. No. 1071, 75 Comg. $1^{\text {th }}$ Sess., al 2 (1937); see alko S, Rep. No. 818. 75'l Cong. Is! Sess, al 2 (1937). Chairman Lea achoed these views ott the floor of the House: "This is the most far-reaching agretsment ever entered into berween capital and labor ill thus or any ather country. "8: Cong. Ret 6051.75h Cong. I"Sess. (June 21.1937): see diso remarks of Ser. Wagner, id. at 6222. For Furher prase of the agreement, see remarks of Rep. Wolvertot, $i d$ at 6085; remarks of Rep. Martir af Colorado, id, at 6080 ; remarks of Rep. Mapes, id. ar 6057 : romarks of Rep, Cole of varyland, $a d$, at 6088 ; remarks of Rep. Mead, id. at $61099-90$, remarks of Rep. Raybum, id. 
gi $6092 ;$ remarks of 5en. Clark, id a16222-23

Ch. 347.44 Stat. 577 (1926).

"Toxas of New Orteans Railpod Co. v Brotherhood of Raihwa and Steanship Clerks 281 U.S 548 (1930) (Justice McReynolds did not participale). See also Virginian Railway Co. v: Swem Federation, No, 40, 300 U.S. 515 (1937) (unahimously upholding 1934 amendments to the Ac1); Woshington, Nrginto o Harwand Coach Co. $N L R B, 301$ U.S. 142 (1937) (unanimously upholding application of National Labor Relations Ace to interstate bus company); MLRB y Jones \& Langhlin Steet Corp. 101 U.S. I (1937) (upholding apphication of NLRA to stect

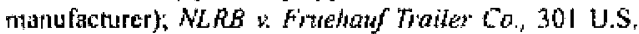
49 (1937) (upliolding application of NLRA to traler manufacturer); NLRB y Friedmon-Haty Marks Clahng $C_{0}$., $30 !$ U.S. 58 (1937) (upholding applicalion of NLRA 10 elothng manufacnurer); Associared Press y NLRA. 301 U.S. I03 (1937) (upholding application of NLRA to wire service company)

Chairmun Lea stated that ${ }^{+4}[1$ is the belief of the rommittee that this act, and particularly is substantial features, will be held constitutional should the Suprene Court be called upon for its decision." 31 Cong. Rec. 6081 , 75, Cong. [" Sess. (June 1,1937 ). See also id at 6302 (Rep. Doughton professes faith in constitutionality of Carrier Taxing Aat and Railrond Retitement Act of 1937\% id. at 6090-91 (Rep. Jenkins professes belief in constitucionalily of Railroad Retirement Act of 1937 ); id. at 6093 (Rep. Crosser protesses foith in constitutionality of Railroad Retirement Act of 1937); ad. at 6222 (Sen. Wagner expresses confidence in the constimulionality of the $1935 \mathrm{Al}$ ts and of the Railirond Relirement Act of 1937): id. al 6087 (Rep. Cale of Maryland profisses faith in the constitutionality of the I 435 Acts) idf al 6092 (Rep. Raybum does the same); id. at 6093 (Rep. Crosser does the same). Id. at 608 i.

"Id. al 6087 . This was repteated several times on the floor. Chairfman Lea repotted that "The two great groups enter. ing into agreement resulting irt this legislation have agred not to contest it." $/ d$ at $608 \mathrm{l}$. Rep. Wolverton reported that "it has been agreed by each of the parties that they will upon ils enactment support and defend its pruvisions." Id. at 6085 . In the Sentate Wagner reported that "the railroads agreed with the representitives of the workers that If this ineasure were enacted they would not test its const!htionality, but accept it as law of the land." It. at 6222 . Sea also remarks of Sen. Wheeler. id. 6224-25 (suggesting that a stockholder or sinal] roitroad might nevertheless bring a contes1): remarks of Rep, Lea, $i d$. at 608 I (hinling at the sante). For far that floor amendinents would unravel the deal betwen the rat roads and the unions, the Senate decisively rejected two amendments offered by Wheeler. See id at 6224-27.

Rep. Mapes added: "la is further understood that any suit or suits now pending in court to test the constitutionality of the existing raitroad retirentent law will be withdrawi." $J d$. at 6087 ; ye" also remarks of Rep. Wolverton, if a1 6085. Because the 1937 Act expressly rapealed the 1935 Act, the Court of Appeals directed the District Cour io dismiss the Alon suic on the grounds that it had become moot. Thus the 1935 Act was never challenged betore the Suprene Court See $B$. \& $O$. R. Co. " Magruder, 77 I. Supp. 156, 157 (D. Md., 1948).

In Coliforria watimer, 305 (IS, 255 (1938), the state sought an injunction against collection of the tax from its own State Belt Railroad. The Cout appears to have been unsure exactly what the bill clained. As Jistice Brandeis put it, "The bill asserts, apparently, that as a matter of statitory construction. the federal [retirement] system is not applicable to the employees of the State Bell Railroad: and apparenty that if conglrued as applicable to them, the legislation is unconstitutional. " $d d$ at 257. The stale's theory was that applisation of the Carrier Taxing Act to the State Belt Railroad would constitute taxation of a state instrumettality in violation of the prituciple of intergovernmenlal tox immunity. See Brief or Motion For Leave to File Bill of Complaint, 6, 20-21, Molion For Leave to File and Brief of Coniplaitant State of Califomia in Suppor of Motion for Leave to File Bill of Complaint $\$-20$, 28-29, 44-A5; Supplemental Briel of Complainant Stale of California an Defendants' Motion co Distriss Bill of Complaint. 10-18. In this last docwnent. filed after doubt was cast on the intergovernmental immunity claim by the Court ${ }^{1} \mathrm{de}$ ciscon in Helwethg r: Gerhord, 304 U.S. 405 (1938), the state also contended that the 1937 aots were generally unconstitutional. Id. at 18-21. The relief prayed for, however, was nol that the ferderal railroat retirement act legislation be declared unconstitulional. It was instead more modestly that it "be declared inapplicable to the State Belt Raitrond." 305 U.S. at 258 . Because the Cout dismissof the bilt as without equity the opinion reached neither the statafory nor the constihutional issue. The slate again sought exemption from the Carrier Taxing Act under the principle of intergovernmental immbily, again wilhoul success, in Slate of Califormat v Anglim, 37 F. Supp 663 (N.D. Cal.,

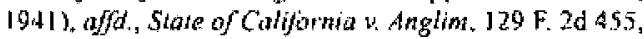
459 (9th Cir, 1942), cent den., 317 U.S. 669 (1942). In two cases lower courts held parties exempl from the Carnet Taxing Acl as a mater of statutory construction. See Gean S.S. Co. of Sunamah : Allen, 36 F. Supp 851 (M.D. Ga., 194b) aff., 123 F. 2d 469 (5h Cir, 1941): New England Fregh Handling Co. W Harsen, 33 F. Sugp. 610 (D. Mass., 1940). See Robert Stern, "The Comynerce Clause and The Nationat Econorny, $1933-1946$, 59 Harv L. Rew 645,693 (1946) (reponting that the "validily" of the reyised retirenient program thas never been chalfenged"). ${ }^{16}$ Sef 45 U.S.C. 231 et sey; 26 U.S.C. $3221-3232$. 117262 U.S. $447\{[92\})$

"Act of Nov. 23, 1921, c. 135, 42 Stat. 224

262 U.S at 487 . For other Taft Court era cases rebuAing chaltenges to fedenal spending on the basis of Mellon's taxpayer standing doctune, see. E.g. Elliall v. White, $23 \mathrm{E}$. 2d 997 (1928) (rejecting petition for injunction to prohibit appropriations for salaries for federal clapplains); Whetess 1. Mellon, 10 F. 2d 893 (1926) trejecting suit to enjoin enforcement of act providing for adjusted compensation for war veterans).

Edward S, Corwin, Twilight of the Supreme Court $176(19) 4)$

See Samuel J. Konefsky, Chier Justice Stone and the Supreme Court 102 n. II (19-45); Carl Swisher. Auterican Constitutional Development 838 (2d ed. 1954); Dean Alfange, The Supreme Court and the National Will $178-$ $80,205(1937)$

${ }^{129}$ Benjanin F. Wright: The Growth of American Consitutional Law 194 (1942).

1 ld. at 183

124 See Alabana Fower Co u lckes, 302 U,S. 464, $478-79$ 
(1938); Duke Power v Gremuood County, 302 U.S. 4BS (193B); Califormia Woier Serv 4 Redding, 304 U.S. 252 (1938); City of Allagan v Corsumers Power Co, 71 F. $2 \mathrm{~d}$ 477,480 (6th Cir., 1934 ) cert denied, 293 U.S. 586 (1934): Central Whinois Puh Sarv Co. w Citr of Bushnelt, $109 \mathrm{~F}$. 2d 26, 29 (7th Cir., 1940); Duke Power Co. v. Grenwood Coumb, 91 F. 2d 665, 676 (4th Cir. 1937); Greennood Cowny y. Duke Power, 81 F. 2d 986, 997 (4th Cir., 1936); Athansas-Mo. Power Co. W City of Kenneat, 78 F. 20911 . 914 (8th Cir. 1935); lowa S. Uil. Co. Town of Lanom. 11 F. Supp. 581 , 585 (S.D. I0wa, 1935); Missouri Power \& Lighi Co. w Cily of La Plala, IO F. Supp. 653 (E.D. Mo. 1935); Missouri Uhilities Co 1 City of Califomia, 8 F. Supp. 454, 464 (W.D. Mo. 1934). See aLo Perkins 1. Lukens Sied Co., 310 LiS. 113, 125 (1940) (relying on Mellon in denying standing to challange detemination made 11nder Public Conlacts Act); Groff * Town of Seward, 9 Alaska 205 (1937) (denying plaintiff standing to challenge Public Works Administration).

Mellon's broader justiciability doctrine whs also invoked by the lower couns in repulsing altacks on the National Labor Relations Act, see Belhlehem Shifbuilding Corp. Wvionder, I4 F. Supp. 20I, 207 (S.D. Cal., 1936); Ohio Custont Garment Co. v. Lind, 13 F. Supp. 533, 536 (S.D. Ohio, 1936); the second FrazierLetnke Act, see In re Chillon. 16 F. Supp. 14,16 (D) Col., 1936); in re Paul. 13 F. Supp. 645, 647 (S.D. lowa, 1936); the Emergency Relief Appropriation Act of 1935, see Barnidge $v$. Unired Slotes, 101 F. 2d 295. 298 (8th Cir., 1939); the Securities and Exchange Conmission, see Delroin Edison Co. $v$ Secwriles de Exchange Commission, 119 F. 2d 730,740 (6th Cir. 1941); certain provisions of the amended Agriculnual Adjustment Act, see Wallace v: Ganley; 95 F, 2d 364. 366 (D.C. Cir, 1938); and the Tennessee Valley A whority, sec Frahn v. Trincsse Valley Anchority, $41 \mathrm{~F}$. Supp. 83. 84, 86 (N.D. Ala., 1941); Tennessee Volley A whority Ashwander, $78 \mathrm{~F}$. 2d 578, 583 ( 5 th Cir, 1935); see atso Tennessee Elacuic Power Co. w Tonnessed Valloy A whoris, 306 U.S. 118, 137 (19.39); Ashmonder v. Tinnosse Valley Awhorty, 297 U.S. 288 (1936).

48 Stat. $22,23(1933)$.

126 48 Stal. 257, 258(1933)

${ }^{123} 49$ stat $1,4(1935)$.

${ }^{12 k} 49$ Stal. $1363,1364(1936)$.

49 Stat. 1597, 1608 (1936). As Carl Swisher put it, "Con. gress. . cottinued to make appropriations of this kind: largely intrinte from judicial scrutiny." Swisher, supta note 121 at $838-39$. The Supreme Court and the lower federal couts also rejected chatienges to the Hone Ownars Loan Corporation on standing grounds. See Kay k: Uniled Slates. 303 U.S. I (1938). See also Pillman u Home Ohwers Loan Corp, 308 U.S 2 I (1939) (assuming constifutionality of Hone Owners Laan Corpl, Craves wew York ex rel. O'Keefe, 306 U.S. 466, 492 (1939) (assuming constitutionality of Home Owhers Ladn Corplli Virited Siats 4 Hil, 90 F.2d 573 (3d Cir, 1937), cert den, 302 U.S. 736 (J937), reh'g den. 302 U.S. 779 ( 1937 ) (upholding constinutionality of Home Ower's Loon Corponation). The Fedgral Emergency Relief Act. 48 Sial. 55, 56 (1933). was subjected to an urtsuccesful "collateral attuck" in Langer 4: United Siater, 76 F. 2d 817, 824-25 (Bth Cir. 1935). where the courl upheld the Act as a legitimate exercise of Congress's power to appropriate money for the general wel fare. In any event, the court beld, ciling Aassachusets 1: Mellon, 262 U.S. 447 (1923), Frothinghom's companion case, "no personal right of amy appellant is infringed." and even if the Act constituled an invasion of slate power "still only an abstuacl question of polilical constintional law would be presented, with which the courts are not concemed." $I d$ at 825 .

111) Act of May 12, 1933, ch. 25, 48 Stat. 31 .

12I $/ d$, , section $8(1)$.

${ }^{172}$ Asthur M. Schlesinger, Jr- The Age or Roosevelt: The Coming of the New Deal 97 (1959).

In a 1932 campaign speech Roosevclt argued that any farm plan "must finance itself. Agriculnure has at no lime sought and does not now seek any such access to the public treasury as was provided by the furile and costly altempts al price stabilization by the Foteral Fann Board. It seeks only equality of opportunily with tariff-protected industry." Raymond Moley. The First New Deal 250 (1966).

Acl of May 12, 1933, ch. 25, Sections 9, 12,48 Stat. 31 13: Unded Siates $v$ Butler; 297 U.S. I, 57-61 (1936). The dissent did not lake issue with the majority on the question of standing. See 297 U, 5 al 78 (Stone, 1., dissenting). Sue also Alfange, supra note I21, st 184, $187-88$.

${ }_{196} 297$ U.S. 1 (1936).

${ }^{17} / d$. at 68 . Kelly and Harbison reported "a numor given wide credence in Washinglot" that "assened that Chicf Justice Hughes had at first believed the stante constitutional, but that he had ultimately voted with the majority orly because be thought another 5-10-4 decision would seriously damage the Coun's prestige." Alfred H. Kelly, et al., The American Constitution: 1ts Origins and Development 750 (ath ed. 1970 ). Hardd ickes diary reveals that Homer Cunutings repeated this gossip at a Cabinel meating in atrly 1936. lckes, supra note 46, at 535-36.

Alfarge supro note 121, at 180-81. See F. G. Vogl d Sons, Int : Rothensice, II F. Supp. 225,226 (E.D. Pa., $1935)$.

49 Stat. II 48 (1936).

${ }^{1413}$ Sie Swisher, supia note 121, at 902: Frank B. Freidel, Franklìn D. Roosevelt: A Rendwavous Wilh Destiny 234 (1990), Stern, supra nole 115, at 689-90; Richard Kirkendat, "The New Deal and Agriculnure," in Braeman, Bremmer \& Brody, eds. The New Deal: The National Level 94 (1975).

80 Cong. Rec. 1778, 74" Cong. 2nd Sess (February $(1,1936)$.

SEe Note, "Soil Conservalion and Domestic Allolment Act," 24 Geo. L. J. 962, 965-67 (1936).

"in) Stem, sup'a note 115, a1 689-90. Anthor Schlesinge: reports that Secretary of Agriculture Henry Wallace "was aware in 1935 that AAA, in its original form, was beginning to play oul. Acreage reduction was breaking down in certain areas, partly because too many of the farmers (as in wheal) were slaying oulside the system. partly because increases in produclivity mullitied the effect of reducing acreage. . . Wallace, as he cold Itertsy Morgenthau on a walk to work on a Eall morning in 1935, would be glad enough to have the processing tax dectared unconstinutional, so that AAA would thereafter get its money from the general lax funds. It was clear 10 hint, and even clearer to Howard R. Tolley, head of the Progran Planning Division, that AAA would have to evolve in new directions." Schlesinger, 
supro note 132, at 82.

52 Stat, 31 (1938).

1.4. See Cusbman, supra note 70, at 191-92, 196-97.

Nth 297 U'S. al 67-64

"See ch. 86, 42 Stut. 187 (1921) (amended by the Grain Futures Act, ch, 369, 42 Stal. 998 (1922)) (codihied as amended at 7 U,S.C. section 1-26 (1992)). 259 U.S. 44 (1922).

Id, at $66-68$.

1d. at $68-69$

ISI $\mathrm{ld}$ at 69 .

is Sec Act of Aug. 15.1921, ch. 64, 42 Stal. 159

(1921) (current version al 7 U.S.C. section 181.229

$(1992))$.

See Slojford $v$ Wallace 258 U.S. 495 (1922).

See ch. 369. 42 Stal. 998 (1922) (amended by the

Commodity Exchange Act, eh. 545,49 Stat 1491 (i936) (codiujed as amended at 7 U.S.C. section 1-26 (1992)).

262 U.S. : (1923).

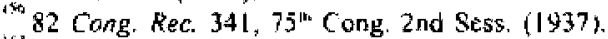

"Id. at 340-41. Pope agreed with Senator MoKellar that Congress ought 10 "make perfectly clear th the Court.

. whal Congress had in mind by staling the purpose of the bill on its face." predicting that every menber would see the importance of the bill's legislative findings concerning the effeci of unreguigted agricultual marketing on interstale comunerce "when the Court comtes to pass upon the constitutionality of the pending measure. "/d. at 341 . ISt at 34 !.

199. 307 U.S. 38 (1939).

Brief for the United States al 110 (citalions amitled). 307 U.S. a 47.

102 Robert Jackson. The Struggle for Judicial Supremacy 238 (1941). See also Swisher, supra note 12l, a1 9\$7; Comment, "Interstate Commerce- Fed. eral Regulation of Tobacco Markeling Held Constitutonal," 52 Harw L. Rev 1364 (1939).

163 U.S. $12(1927)$.

${ }^{10 *}$ Anong them were NRA head General fiugl Johnson, NRA comsel Donald Richberg. and Commissioner of Slatistics lsador l.ubin, Bruce A. Murphy, The Brandeis/Frankfurter Conoclion 167 (1982).

Also it attendance were presidential gide Tonmy Corcoran, Senator Robert Wagner, and Charles Wyzanski, the talented young Labor Departmenl Solicitor who would ultimately defend the Social Security Acl before the Coun. Id, at 168 ,

See Murphy, sivpra note 164, at 165-69; see also Elizabeth Brandeis Rushenbush to 1.DB, Sept. 30. 1933; EBR io LDB, Sept. 24, 1933: Lincoin Filene to LDB. Dee. 26, 1933; W. L. Stoddard to L.DB, Dec. 27 , 1931: W. I. Siuddand to Lincoln Fîlene, Dec. 27. 1933; Tom Corcoran to Paul Raushenbush, Jan. 26, 1934; Paut Raushenbush to Tom Corcoran, Jan. 26. 1934 (Brandeis Papets, University of Lousvilhe, microform).
${ }^{467}$ Murphy, supro nole 164, at I69; EBR to LDB, Feb. 5 , 1934; Beulah Amiton to EBR, Feb. 6, 1934: A.J Altmeycr to EBR, Feb. 9, 1934: EBR to IDB, Feh, 10, 1934; EBR to L.DB, Feb. 12, 1934; EBR to LDB, Feb. 15, 1934 (Brandeis apers, University of louisville, micro form)

Mutphys supra note 164, at 169-75; FDR to FF, Jurte 11. 1934, in Roosevelt and Frankfurter: Their Corrtspondence, 1928-1945 122-23 (Max Freedman, annob. 1968); Ton Corcotan and Ben Cohen to FF, June 18, 1934. id. at 123-26. See also Schlesinger, supro note 132 , at $30 \mathrm{~J}$. 03, 305-06; Joseph P. I ash, Dealers und Drearners 24445 (1988); Williant E. Leuclutenburg, Franklia D. Roosevelt and the New Deal 130 (1963).

19. Murphy, supra nole 164 , at 176-77,

${ }^{17}$ Stewand Machine Co. v Davis, 301 U.S. 548 (1937). IT1 at $591-92$.

301 U.S. al 598 (McReynolds. 1. dissenting); $30 \mathrm{~s}$ U.S. at 616 (Butler, 1. dissenting).

17. Id. al 609 (Sutherland, J, distenting).

174 See George Sutherland to Richard R I yman. Jan, 21. 1938; George Suthertand to Mr. Preston (initials unknown), Jan. 18, 1938; George Sutherland to Wicholas Murray Butler, fan, 12, 1938, Eox 6. Sutheriand $M_{15} S$ S, IC.

Alsop \& Catledge, supra note 1, al 206; Pusey, supra note 1 , al 760 .

"I agree that the payroll lax lavied is an excise within the power of Congress; that the devotion of not more than $90 \%$ of it to the credit of employers in states which require the payment of a similar lax under so-called unemployment-lax laws is not on unconstirutional use of the proceeds of the federat tax: that the proviston making the adoption by tite state of art unemployment law of a specified sharacter a condition precedent to the credit of the tax does not render the law inyalid." 301 U.S. at 609-10 (Sutherjand, J., disserming).

Id. at $613+14$

171) 30 U.S. al 615-16 (Sulhertand, $f$, dissenting).

17") falvering w Davis, 301 U.S. 619 (1937).

"Carmichat v. Southern Coal \& Coke Co, 301 U.S. $495(1937)$

IAz al 527 (MeReynolds, J., dissenling).

$1 d$

19. $l d$ at $527-30$

Itis $/ d$, at 530 .

10. $J d$, al $530-31$.

iat at 531 .

1.67 Murphy, sapra note 164, at 93-96

14k Whesler, supra note 1, at 329.

Ity Baker, supra note 84, at $49-50$

Peler H. Irons. The New Deal Lawyers 248 (198:)

Baker, stupra note 84, at 50 (citing The Now rork Tines, July 6, 1935, at 2).

Id.

${ }^{14 .}$ The New York Times, Jan. 7, 1937, p. 1 